\title{
HORNICKÉ REVÍRY VRCHOLNÉHO STŘEDOVĚKU A RANÉHO NOVOVĚKU VE SROVNÁVACÍM POHLEDU
}

\author{
KRYŠTOF DERNER - PETR HRUBÝ - ONDŘEJ MALINA - JOSEF VEČEŘA
}

\begin{abstract}
Abstrakt: Poznání historických báňských regionů dosáhlo v radě prípadů míry, která nás nutí zamyslet se jak nad jejich společnými, tak rozdilnými strukturálními a vývojovými rysy. Nabizí se jich pritom celá řada, at' už jde o absolutní i relativni chronologii počátků a nejvýznamnějšich fází těžby, odlišně fungujici organizaci úpravnických a hutnických provozů, anebo lokálně specifický vztah mezi hornictvím a osídlením. Krokem vpřed je už jen samotná definice srovnávacích kritérií, která musí zohledňovat přistupy mnoha oborů (montánni archeologie, ložisková geologie a mineralogie, báňská historie, poprípadě navazující př́rodní vědy). Teprve tato kritéria ukazují, ve kterých revírech má největši smysl hledat odpovědi na konkrétni historické otázky.
\end{abstract}

Klíčová slova: montánní archeologie - geologie - báňskohistorický průzkum - těžba a zpracování surovin-montánni krajina-LiDAR - GIS.

\section{Mining regions in the high Middle Ages and the early modern age viewed in terms of comparison}

\begin{abstract}
The study of historical mining regions has in a number of cases reached a level that makes us consider their shared and different structural and development features. There are many, both the absolute and relative chronology of the origins and the key phases of mining, differently functioning organisation of the processing and metallurgy workshops, or a locally specific relationship between mining and settlement. An important step forward appears to be the definition of comparative criteria which must involve approaches of numerous disciplines (mining archaeology, deposit geology and mineralogy, mining history, as well as related natural sciences). It is only these criteria that show in which regions we should seek answers to particular historical questions.
\end{abstract}

Key words: mining archaeology - geology - mining-historical research - mining and processing of raw materials - mining landscape - LiDAR - GIS.

\section{1 Úvod}

Co mají společného středověké hornické areály Kremsiger u Přísečnice ve východních Krušných horách, Buchberg nedaleko Přibyslavi na Českomoravské vrchovině nebo město Horní Blatná $\mathrm{v}$ západním Krušnohoří? Je to jen vazba na historickou hornickou činnost, nebo jsou souvislosti hlubší? Jakou roli hrály tyto lokality v organizaci hornictví? Zodpovězení těchto otázek vyžaduje komplexní pohled v širších územních i nadregionálních souvislostech. V průběhu řešení česko-saského projektu ArchaeoMontan 2018 se ukázaly výrazné rozdíly mezi vývojem hornictví v západním a východním Krušnohoří. Snaha porovnat obě části historického hornického regionu záhy odhalila problém správné metodiky, kdy se nesrovnalosti projevovaly už na úrovni komparace dílčích lokalit. Například hornické sídliště Kremsiger má mnoho shodných znaků se soudobými důlními areály v saském Podkrušnohoří i na Českomoravské vrchovině, ale v blízkém západním Krušnohoří již analogie nenalézáme. Masivní kolonizace západního Krušnohoří v první polovině 16. století, při níž vznikla hornická centra Horní Blatná či Boží Dar, má zdánlivě podobný průběh jako v oblastech na východ od Klínovce. Ukazuje se však, že východní Krušnohoří mělo zcela odlišnou výchozí pozici a tou byly mnohem starší počátky a rozvoj sídelní infrastruktury. Potřeba vhodných analogií ke krušnohorským lokalitám ukázala, že srovnávat tamní historické montánní areály bez nadregionálních báňskohistorických a sídelních souvislostí není jednoduché ani při solidní výpovědi archeologických pramenů.

Cílem příspěvku bylo pokusit se nejprve najít metodiku k uchopení základních rysů vývoje předindustriálního hornictví v různých regionech a nalezení kritérií, podle nichž by bylo možné tyto regiony porovnávat. Přitom se objevilo množství problémů, jejichž metodické překonání je podmínkou dalšího montánně archeologického a báňskohistorického výzkumu. 
První klíčovou otázkou je, jak velké celky lze smysluplně srovnávat a jak je definovat. Text se snaží pracovat nejen s regiony ve smyslu geomorfologických jednotek (východní a západní Krušnohoří, Jeseníky, Českomoravská vrchovina), ale i s menšími oblastmi (Zlaté Hory). Jejich vymezení je spíše účelové a odpovídá převážně ohniskům současného montánně archeologického a báňskohistorického výzkumu. Historický vývoj je v některých regionech na první pohled podobný až synchronní, v jiných, např́íklad ve východním Krušnohoří, není představa jednotného vývoje celé oblasti udržitelná (Hrubý 2016; Derner-Lissek 2018 v tisku; Malina 2018 v tisku; Večeřa 2008). Těžba rud různých kovů zažívala vrcholy v odlišných dobách. Z velké části to jistě souviselo s poptávkou, podnikatelskou aktivitou vrchnosti i měšt’anů. Smysluplnější se jevilo pracovat s menším územím, které tradičně vystihuje pojem „revír“. Ukázalo se však, že tento pojem je užíán velmi různě a obtížně se aplikuje na oblasti středověké těžby. Prvním úkolem byla tedy přijatelná definice revíru, nebo poukaz na jeho různé významy.

Podobně obtížná je otázka metod či vůbec možností výzkumu otevírání, nebo naopak opouštění dolů, objemu a tempa těžby v různých obdobích, a tím možností periodizace fází vzestupu a úpadku středověkého až raně novověkého hornictví v různých revírech či na konkrétních dolech. Až na výjimky, k nimž patří například od 14. století účty mincovny Freiberg (Burghardt 2018), je výzkum v prredstatistickém období, často pak při úplné absenci spolehlivých záznamů o výtěžcích, odkázán na metodicky a pramenně improvizované sledování nepřímých indikátorů tempa těžby, a tím významu hornických revírů či jednotlivých středisek. Archeologie v kombinaci s dálkovým průzkumem, popř́ípadě geofyzikální prospekcí umožňuje v tomto ohledu pouze posouzení rozsahu a stupně rozvoje důlních, úpravnických a hutnických pracovišt', jakož i sekundární infrastruktury, tzn. především hornických sídlišt'. Samotné hornické práce, zejména ze starších období (13.-15. století), však v nejednom případě nelze spolehlivě datovat vůbec, a to ani navzdory existenci dílčích písemných pramenů.

Text se pokouší uchopit kategorizaci hornických center i menších sídel, jejichž přítomnost či absence mohou napovědět, jakého stupně rozvoje ta či ona oblast $\mathrm{v}$ jednotlivých dobách dosáhla, a pokusit se o pilotní srovnání hornických regionů, a následně tím i lépe definovat sídelní a báňskohistorický kontext zkoumaných míst. Text se snaží reagovat i na značný rozmach montánně archeologického bádání za posledních 15 let nejen v České republice, ale i v okolní Evropě. V české archeologii zformuloval základní teoretický aparát před 25 lety Karel Nováček, ale nové výzkumy a prospekce starých důlních areálů, kterých jsou dnes desítky, nás nutí po čtvrtstoletí rekapitulovat. Zároveň se snažíme udržet smysluplnou teoretickou strukturu montánně archeologického studia, opřenou pokud možno i o názvosloví a kategorizaci jevů, s nimiž montánní archeologie pracuje, ale které prritom patří do jiných oborů. Jejich recepce archeology a historiky není vždy přesná.

\section{Otázka definice hornického revíru}

Pojem revír lze chápat více způsoby, avšak při studiu historické těžby rud převažují tři hlediska: geologické, báňskohistorické a archeologické. Všechna tato hlediska se přitom prolínají, nejde tedy o teoreticky a metodicky ostře oddělené kategorie. Geologický pohled je oběma zbylými ovlivněn nejméně, protože geologický základ se v zásadě nemění. Pohled báňskohistorický vychází ze studia dostupných písemných pramenů, závisí výrazně na historickém období, které je předmětem studia a při výzkumu nejmladší báňské historie se nejednou př̌krývá s přístupem čistě báňským. Archeologický pohled se opírá především o existenci montánních terénních reliktů.

V geologické literatuře se vyskytuje řada definic odpovídajících svou náplní termínu revír (revír, rajón, distrikt, rudné pole, okrsek). Shoda panuje v tom, že se jedná o oblast splňující dvě podmínky. Nachází se v ní několik blizko sebe ležicich ložisek stejného genetického typu (druhu suroviny, minerální parageneze), a ta jsou vázána na stejnou geologickou nebo tektonickou strukturu (Vaněček 1995; Rozložník a kol. 1987; Smirnov 1983; Ilavský-Sattran 1980). Plošný rozsah se může měnit s mírou poznání geologické stavby (vymezení stejné geologické struktury) 
a zahrnutím jen ložisek nebo i výskytů a indicií. Ložisko je totiž definováno jako akumulace užitkových minerálů (hornin), kterou je účelné v daných ekonomických a geografických podmínkách průmyslově využivat (Vaněček 1995). Této definici nemusí odpovídat území s historickým montánním reliéfem, který je pozůstatkem jen vyhledávacích (průzkumných) prácí, což mnohdy nelze bezpečně rozlišit. Další problém může nastat v územích bohatých na nerostné suroviny, kde dochází k překryvu různých ložisek. Přibíráním surovin bychom v extrémním případě mohli dospět například ke stanovení rudního revíru v rozsahu celých Krušných hor.

Z pohledu ložiskového se jedná o území vymezené geologicko-tektonickými a minerálními parametry a na metalogenetické mapě ČSSR se nazývá ložiskovým rajónem (Ilavský-Sattran 1980). Pro území naší republiky byla vytištěna metalogenetická mapa v měřítku $1: 500000$ (Sattran-Ilavský 1981), sestavená na základě metalogenetických map 1: 200000 z let 19601964, které nebyly publikovány, ale jsou pouze v mapovém archivu C̆GS (http://www.geology. cz/app/archiv), kde jsou i mapy podrobnějších měřítek pro některé části území. Pouze pro dílčí území byly publikovány podrobnější mapy různých měřítek, např́íklad pro Krušné hory dvoudílná mapa v měřítku 1:100 000 (Hösel-Breiter 1995). Určitou představu o rozmístění ložisek lze získat z map 1 : 50 000, př́ípadně z map Surovinového informačního systému (https://mapy. geology.cz/suris).

Z pohledu horní správy, resp. Obecného horního zákona z roku 1854, je horním revírem území s přítomností několika prostorově sblížených podniků různých těžařu, jejichž využití je účelné řešit společně. Přesná definice je uvedena v § 11: „Doly, které jsou prrirozeně spojeny polohou a stejnými držebními, provozními nebo jinými poměry, mohou býti sloučeny $v$ báňský revír. Báňské úr̆ady urči rozsah báňských revirů a vykonaji připravy $k$ jejich utvoření v dohodě s těmi, jichž se to týká. Každý revír budiž označen určitým jménem“(Peters-Koschin 1930). Tento princip byl $\mathrm{v}$ mladších dějinách reálně uplatňován pouze $\mathrm{v}$ uhelných pánvích. V předindustriálním období tomuto termínu odpovídalo území působnosti horního úřadu, pro které byl vydán speciální horní řád. Návrh oborové normy ON 440001 vymezuje revír (oblast) jako ,souvislou územni oblast, zahrnujici dobývaci prostory ložiska nebo vice ložisek" (ON 440001 č. 16, 17). Historickým ekvivalentem dnešních dobývacích prostorů byly dřivější dolové míry, případně středověké hory (podle Ius regale montanorum - IRM). Báňský revír je tedy v tomto smyslu administrativní území, vymezené rozsahem souvisejících skupin dolových měr, jejich přebytky, popřípadě prostorem mezi dolovými mírami, a technickým zázemím, nutným k provozu dolu. Plošný rozsah této jednotky se však měnil podle postupujícího propůjčování měr, resp. dobývacích prostorů, změn vlastníků a rozfárání ložiska. Dủležitým faktorem při etablování báňských revírů byl tedy čas. V dalších úvahách o historickém vývoji revírů je proto nutné brát v úvahu časová období jejich existence.

Z báňskohistorického hlediska se v první řadě může jednat o území prostorově definované v konkrétním historickém prameni anebo jejich souboru a fyzicky alespoň přibližně vymezitelné v dnešní krajině. Toto vymezení zpravidla postrádá specifikaci parametrů, podle kterých bylo určeno. Tento pohled se může překrývat s pojmem horní revír. Pro tuto kategorii lze použít označení revír s udáním zdroje (například jílovský revír podle mapy...). U středověkého báňského revíru v drtivé většině př́padů nejsou podklady pro jeho přesné vymezení $\mathrm{k}$ dispozici a lze jej vyčlenit pouze podle útržkovitých zpráv, nejčastěji však jen podle terénních pozůstatků.

Od 16. století jsou pro některé regiony zachovány horní knihy, které již takové vymezení umožňují, ovšem nadále při souběžném vyhodnocování terénních reliktů důlní činnosti. Horní knihy, evidující jednotlivé propůjčky dolových měr, byly vedeny u horních soudů a jejich pomocných orgánů (horních substitucí). Teprve od 18. století existují k propůjčkám dolových měr i jejich mapy.

V Jáchymovském horním řádu nalezneme pojem pohoří, což byla vymezená oblast, v níž mohl perkmistr propůjčovat dolové míry a jejíž jméno muselo být součástí žádosti o propůjčku. Tato oblast nejlépe odpovídá archeologickému, historickému i ložiskovému chápání pojmu revír. Ve správní oblasti Potůčky jsou v horních knihách uvedena pohoří: Rabenberg, Heinrichschacht, Ziegenschacht, Pechöfen, Farbleuthen, Schwimmiger, Heinrichstein, Hirschberg (obr. 1). Podle 
obecného horního zákona je takovému území nejblíže kutaci obvod (území charakterizované jednotlivými parcelami, údolím nebo svahy, jejichž jména a ohraničení jsou obecně známá, nebo rozsáhlejší plochy, jejichž hranice musí být přesně vytyčeny, též Schurfgebiet; Peters-Koschin $1930, \S 15)$. V takovém obvodě může pracovat více zájemců. V př́ípadě, že se jednalo o povolení k vyhledávání nerostných surovin jednomu zájemci, šlo o tzv. výhradni kutiště (Freischurf; Peters-Koschin 1930, § 22-23).

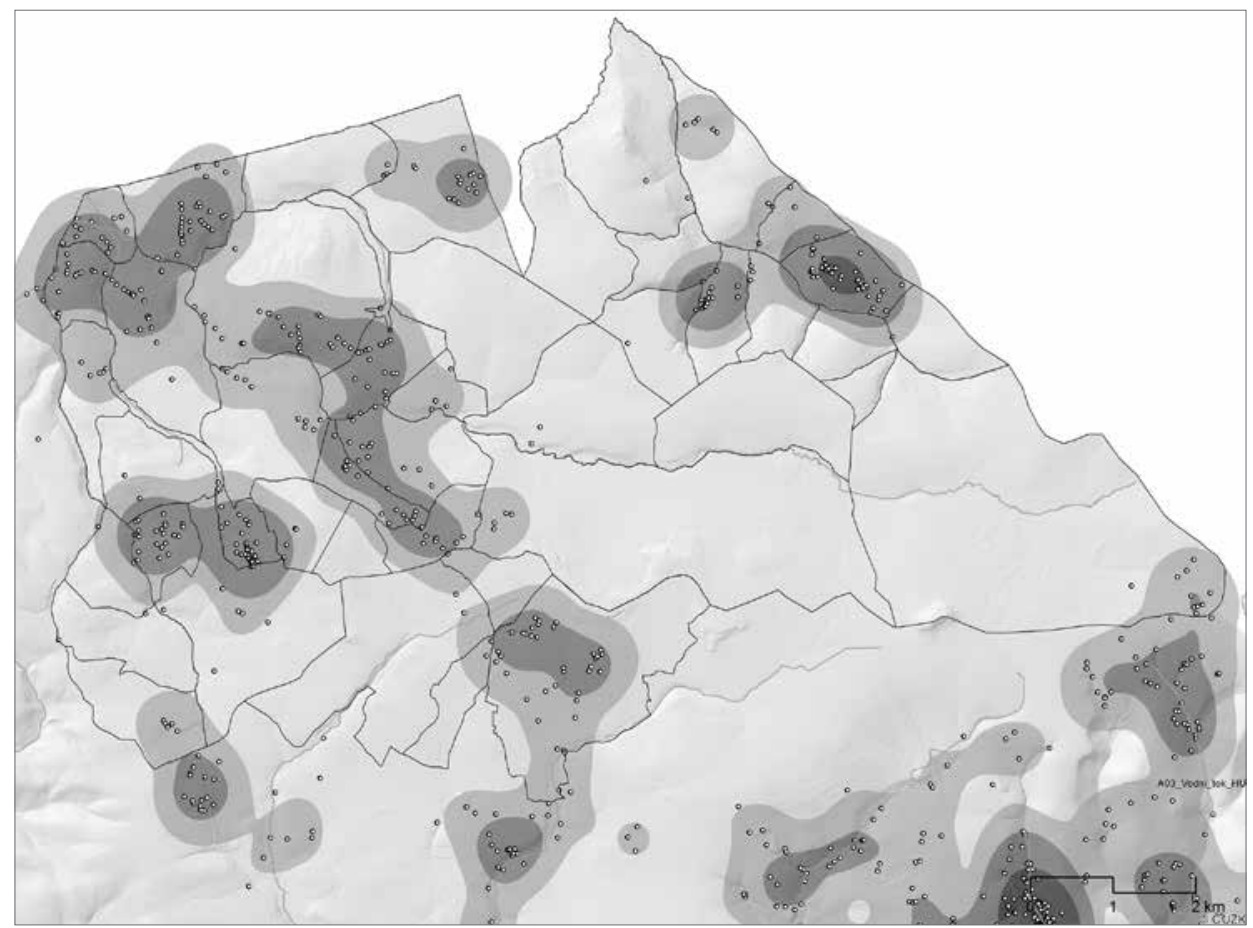

Obr. 1. Rekonstrukce rozsahu revírů a okrsků v prostoru mezi Potůčky a Božím Darem, doplněná o důlní díla z evidence České geologické služby - Geofondu a jejich interpolaci. Podkladová data ČGS - Geofond a ČÚZK.

Abb. 1. Rekonstruktion des Umfangs der Reviere und Distrikte im Raum zwischen Potůčky und Boží Dar, ergänzt um Grubenbaue aus den Unterlagen des Tschechischen Geologischen Dienstes - Geofond und ihre Interpolation. Basisdaten des Tschechischen Geologischen Dienstes - Geofond und Tschechisches Amt für Landesvermessung und Kataster.

Mnohdy je těžké odlišit tato území od oblastí, v nichž byla propůjčována obecná práva na těžbu, často doprovázená dalšími svobodami nebo podíly na urbuře. Za první písemné stopy takovýchto nadání lze považovat i několik listinných privilegií pro města, nejprve samozřejmě královská (1234 - Uničov, 1272 - Jihlava). Privilegium Přemysla Otakara II. z roku 1272 dává Jihlavě na každém vyměřeném dole u Ústí po jednom lánu. Dále byla Jihlavě přiznána práva propůjčovat a vyměřovat míry na horách, které $\mathrm{v}$ Ústí byly nalezeny a které $\mathrm{v}$ budoucnu budou nalezeny mezi Jihlavou a Ústím (CDB V/2, 278 č. 650). Snad šlo o účelové privilegium k perspektivně se rozvíjející důlní činnosti na Pelhřimovsku, které právě mezi Jihlavou a Ústím leží. V pozdější konfirmaci Karla IV. je už připojena univerzální formulace okruhu čtyř mil od města směrem na Moravu. Práva k nálezům zlata, stříbra, olova a jiných kovů v okruhu šesti mil od Brna získali od krále Václava II. i brněnští měštané listinou z 25. března 1297. Text se doslovně odkazuje na shodná práva k dolům, která přísluší Kolínu, Č́slavi a v minulosti i Jihlavě 
(CDM V, 61-62 č. 65). V tomto př́ípadě se za univerzální formulací může skrývat zájem brněnských měšt’anů na důlních podnicích v oblasti svratecké klenby.

Vliv městských správních center na báňský provoz v jejich zázemí ilustrují i další o něco mladší zmínky. Tak je např́iklad roku 1339 nadána vrchnost Př́isečnice možností těžby v okruhu čtyř mil od města s požitky jako ve městě i na dolech. S př́ísečnickou listinou z roku 1339 je obsahově prakticky totožná listina pro Německý Brod z roku 1362, ale bez přesného uvedení rozsahu čtyř mil (CIM II, 574-575). O obvodu čtyř mil předpokládá H. Ermisch, že je to obligatorní okruh určitých pravomocí horního centra podle freiberské předlohy (Ermisch 1887, LV; Stadtrecht Cap. III $\S 4$ / Schott 3, 170). V téže vzdálenosti mělo právo nárokovat si lány a vyměřovat doly město Jihlava v privilegiu Karla IV. z roku 1345 (Tomaschek 1859, 332).

Do stejné kategorie patři privilegia pro vrchnosti těžící ve východním Krušnohoří v 15. a počátkem 16. století. Týkají se povolení těžby a různé úlevy na urbuře, která se vždy vztahují na všechny potenciálně výnosné kovy v oblasti (Derner-Lissek $2018 \mathrm{v}$ tisku). Velikost horního obvodu půl míle v saském Krušnohoří předpokládá W. Schwabenicky (2009). V tomto okruhu např́iklad neměly být jinou vrchností zřizovány trhy, které by novým hornickým centrům konkurovaly. $\mathrm{V}$ daném prŕṕpadě se však jedná spíše o privilegia spojená s lokací nového sídliště.

V současné době probíhá archeologický výzkum řady montánních areálů, k nimž obtížně získáváme písemné zprávy umožňující přesnější představu o báňském revíru. Mnohdy se jedná o území, která nejsou vymezena ani jako rudní revíry. Zejména u středověkých areálů jsme většinou odkázáni jen na povrchové projevy hornické činnosti dokumentované archeologicky. Jedná se zpravidla o území s pozůstatky historické důlní činnosti bez rozlišení, zda se jedná o fázi prospekční, průzkumnou nebo těžební, i když toto rozlišení je důležitým parametrem dalšího interpretačního vyhodnocení studovaného území.

Při archeologickém zkoumání pracujeme s pozůstatky důlní i navazující zpracovatelské činnosti na uceleném území. To můžeme označit jako hornický či montánni areál, pokud nerozlišujeme těžební, úpravnické či sídelní části, ale též pouze jako těžební areál, pokud nejsou evidovány jiné aktivity než těžba či kutání. Skupinu více takových areálů nazýváme okrskem, který může odpovídat ložiskovému rajónu (revíru) nebo báňskému revíru.

Území s jedním nebo větším počtem takových areálů, ale s provozní vazbou na jedno výrobní nebo sídelní centrum, lze označit na základě historických zpráv, případně vodních nebo dopravních děl (to zejména v mladším období), za hornický obvod. Pokud se jedná o správní vazby, používáme označení hornická oblast.

Klíčovým nástrojem montánního výzkumu je digitální model reliéfu (DMR). S výjimkou zcela aplanovaných terénních reliktů zpravidla lze vizualizací terénního reliéfu zviditelnit alespoň nějakou část revíru, kde nebyla povrchová likvidace důsledná. Protože metoda leteckého laserového skenování (LLS či LiDAR) dokáže při stejné či obdobné kvalitě skenování zachytit většinu dochovaných pozůstatků, má relativně rovnoměrné pokrytí.

Z koncentrace a prostorového umístění terénních reliktů lze opět alespoň rámcově usuzovat na rozsah historické těžby, i když přitom zpravidla uniká chronologický a ložiskově geologický rozměr. Jiným problémem je fakt, že např́íklad rozsáhlé plochy kutišt', kde se skutečná těžba nikdy nerozběhla, se dnes jeví jako významné plochy hornické činnosti, ale v minulosti nemusely být chápány jako součást báňských revírů.

Jádra všech zatím zkoumaných revírů se vždy vyznačují i vyšší koncentrací montánních terénních reliktů. Tyto plochy s vyšší koncentrací terénních reliktů a s doklady více různých funkcí (nejčastěji těžební, zpracovatelské, sídelní) představují již zmíněné montánní areály.

Zároveň lze předpokládat, že u mnoha lokalit došlo vlivem chronologického vývoje nebo kvůli změnám těžené suroviny $\mathrm{k}$ přesunu jádra revíru a například odvaly po novověké etapě nemusí indikovat centrum středověkého dobývání, přestože se i podle navržených definic jednalo o totožný těžební areál. Podobný je problém odhadu rozsahu těžby, nebot' většinou není príistupné celé podzemí a odvaly jsou často přetěženy. I v prrípadě, že je podzemí přístupné, nelze jen na základě způsobu ražby nebo těžby od sebe odlišit jednotlivé historické etapy. Jistým předělem je 
použití střelného prachu, i když starší způsoby jako želízkování či sázení ohněm jsou souběžně používány až do 19 . století.

Dobrým nástrojem pro ověřování terénních reliktů detekovaných na digitálním modelu terénního reliéfu je databáze důlních děl, kterou spravuje Česká geologická služba (https://mapy. geology.cz/dulni_dila_poddolovani/). Datová sada zde obsahuje informace z mnoha různých zdrojů, které mají odlišnou přesnost lokalizace i vypovídací schopnost. Některé evidované objekty nemusí být ani důlními díly, ale podle četnosti evidovaných děl lze též usuzovat na oblasti s významnější hornickou činností (obr. 1,2). Tato databáze rovněž obsahuje odkazy na zprávy, z nichž bylo čerpáno.

Z jednotlivých lokalizovaných důlních děl je možno, při zvolení vhodných kritérií, syntetizovat „revíry“ v prostředí GIS i čistě automaticky metodou interpolace. Podobný postup byl již pokusně uplatněn např́íklad pro doly v jižní Francii (Minvielle Larousse 2017). Otázkou je, co

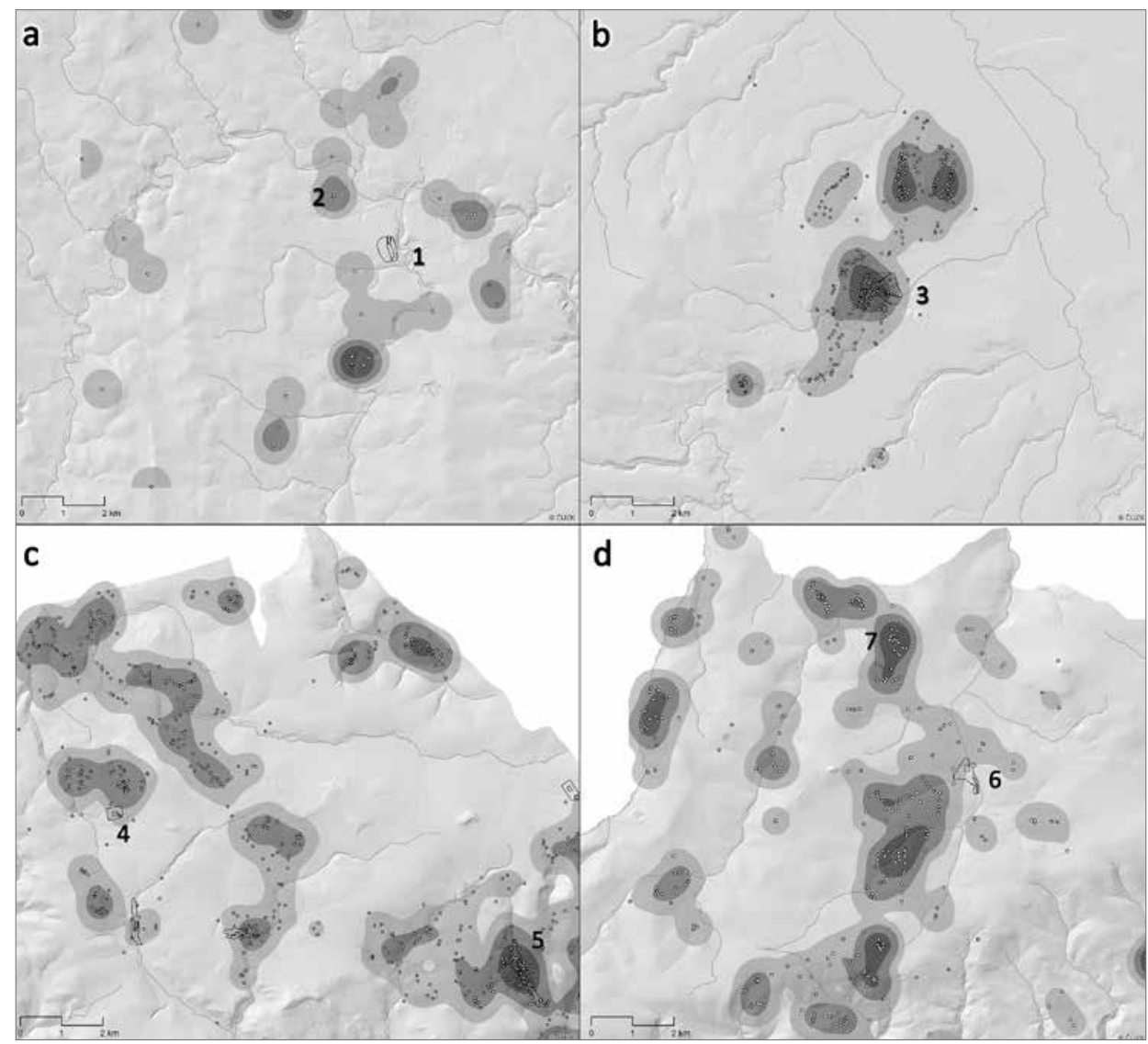

Obr. 2. Evidence důlních děl z databáze České geologické služby - Geofondu, doplněná interpolací, jako indikátor koncentrací těžby. Za pozornost stojí zejména malá hustota evidovaných důlních děl v okolí Jihlavy (a) a naopak výrazná koncentrace v prostoru Kutné Hory (b). Okolí Horní Blatné (c) a obdobně i bývalého města Př́ísečnice (d) ilustruje relativně velkou a zároveň rovnoměrnou distribuci využívaných ložisek. 1 - Jihlava (jádro), 2 - Jihlava - Staré Hory, 3 - Kutná Hora, 4 - Horní Blatná, 5 - Jáchymov, 6 - Př́ísečnice, 7 - Kremsiger. Podkladová data ČGS - Geofond a ČÚZK.

Abb. 2. Erfassung von Grubenbauen aus der Datenbank des Tschechischen Geologischen Dienstes - Geofond, ergänzt um Interpolationen als Indikator für Förderkonzentrationen. Beachtenswert ist besonders die geringe Dichte der erfassten Grubenbaue in der Umgebung von Jihlava (a) und umgekehrt die deutliche Konzentration im Raum von Kutná Hora (b). Die Umgebung von Horní Blatná (c) und damit vergleichbar auch der ehemaligen Stadt Př́́sečnice (d) illustriert eine relativ große und zugleich gleichmäßige Verteilung der genutzten Lagerstätten. 1 - Jihlava (Kern), 2 - Jihlava - Staré Hory, 3 Kutná Hora, 4 - Horní Blatná, 5 - Jáchymov, 6 - Př́́sečnice, 7 - Kremsiger. Basisdaten des Tschechischen Geologischen Dienstes - Geofond und Tschechisches Amt für Landesvermessung und Kataster. 
považovat za jednotku (např. jednotlivou jámu či celé důlní pole) a jaké parametry interpolace nastavit. Výhodou je malé zkreslení subjektivním zásahem badatele, nevýhodou, hlavně u špatně písemně dokumentovaných revírů, riziko ahistorických konstruktů.

Z uvedených definic může vyplývat mnoho obrazů jednoho a téhož revíru. Pro účely báňskohistorického a montánně archeologického výzkumu je nutno zvolit postupy, které nejlépe umožní práci s archeologickou evidencí a zároveň budou, alespoň teoreticky, použitelné ve všech historických báňských revírech. Optimální je proto kombinace studia montánního reliéfu a historických písemných a mapových pramenů k revírům - tyto prameny i přes svou různorodost zprostředkovávají konkrétní chronologický rámec. Slabinou tohoto postupu je, že na jednom území lze teoreticky modelovat hned několik revírů „na sobě“. Jinak se na konkrétním území projevuje stř́bronosný revír v 16. století, a jinak revír cínový v 18. století.

\section{Revír a centrum}

\subsection{Otázka „univerzálních typư“ montánních areálů}

Základem našeho zkoumání jsou větší prostorové jednotky hornické činnosti, ale klíčové místo v jejich rámci zaujímají jen určité jejich části s největší koncentrací těžebních, úpravnických a sídelních aktivit. Lze je definovat i jako jednotlivé lokality (obr. 3). Termín lokalita je chápán v archeologickém smyslu slova, tedy jako zvýšená koncentrace terénních, archeologicky evidovaných reliktů či nálezů, oddělená od jiných lokalit větší či menší plochou s jejich absencí anebo výrazně nižší koncentrací.

Velké rozdíly v charakteru archeologicky zkoumaných lokalit vedly ke snaze tyto rozdíly vysvětlit v širším sídelně historickém kontextu. I když přihlédneme k nerovnoměrnosti archeologického poznání a malému rozsahu výzkumů, vidíme typologicky pestrý obraz. Všechny typy významnějších areálů byly $\mathrm{v}$ různé míře definovány průnikem sídelních, těžebních a zpracovatelských aktivit, ale rozdíly jsou tak velké, že bez pochopení širšího kontextu jejich fungování nelze uspokojivě vysvětlit. Prvním krokem ke srovnání byla proto snaha definovat určité univerzální či obecně rozšířené typy lokalit.

Ve snaze o detailnější třídění montánních areálů došlo pravděpodobně nejdále bádání na Českomoravské vrchovině. Ještě před jejich stručným nástinem je však vhodné krátce diskutovat vztah horních měst a hornických sídlišst a provést základní sumarizaci teoretických otázek.

\subsection{Centrální hornické areály}

\subsubsection{Horni mésta vs. hornická sídliště do poloviny 14. století}

Prvořadá centra vznikala v českém prostředí přirozeně od samých počátků středověké těžby rud ve 13. století. Přitom není vždy podmínkou, aby takové město, označované v odborné literatuře jako horní, vzniklo přímo v místě důlních, úpravnických a hutních pracovišt' a samo se na důlní činnosti přímo podílelo. Podstatná byla nezastupitelná řídící, organizační a obchodně distribuční úloha těchto měst v provozu blízkých dolů (popř. v celé oblasti) a na trhu s kovy (obr. 3). Z hlediska předkládaného pokusu o roztř́íění montánních areálů se v tomto případě často o skutečné montánní areály vlastně nejedná, a lze dokonce i diskutovat, zda skupina nejvýznamnějších horních měst českého středověku do předkládané klasifikace montánních areálů vlastně patř́i.

Nejstarším důlním centrem takového formátu, vznikajícím před polovinou 13. století, je v českém prostředí Jihlava (obr. 3a). Nejlépe poznané montánní areály s přímou vazbou na toto královské horní město se nachází na starohorské dislokační zóně (Hrubý 2011; Hrubý a kol. 2007). Do této kategorie patří nepochybně i Havlíčkův Brod, v jehož okruhu se nacházely dobové velkoprovozy jmenované v listině z 25. října 1258 (CDB V/1, 267 č. 167; Rous 2004). Od konce vlády Přemysla Otakara II. se po zbytek středověku důlním centrem evropských rozměrů stává Kutná Hora (Frolík-Tomášek 2002; Velímský 2007; 2012; Velímský-Končelová 2012). 


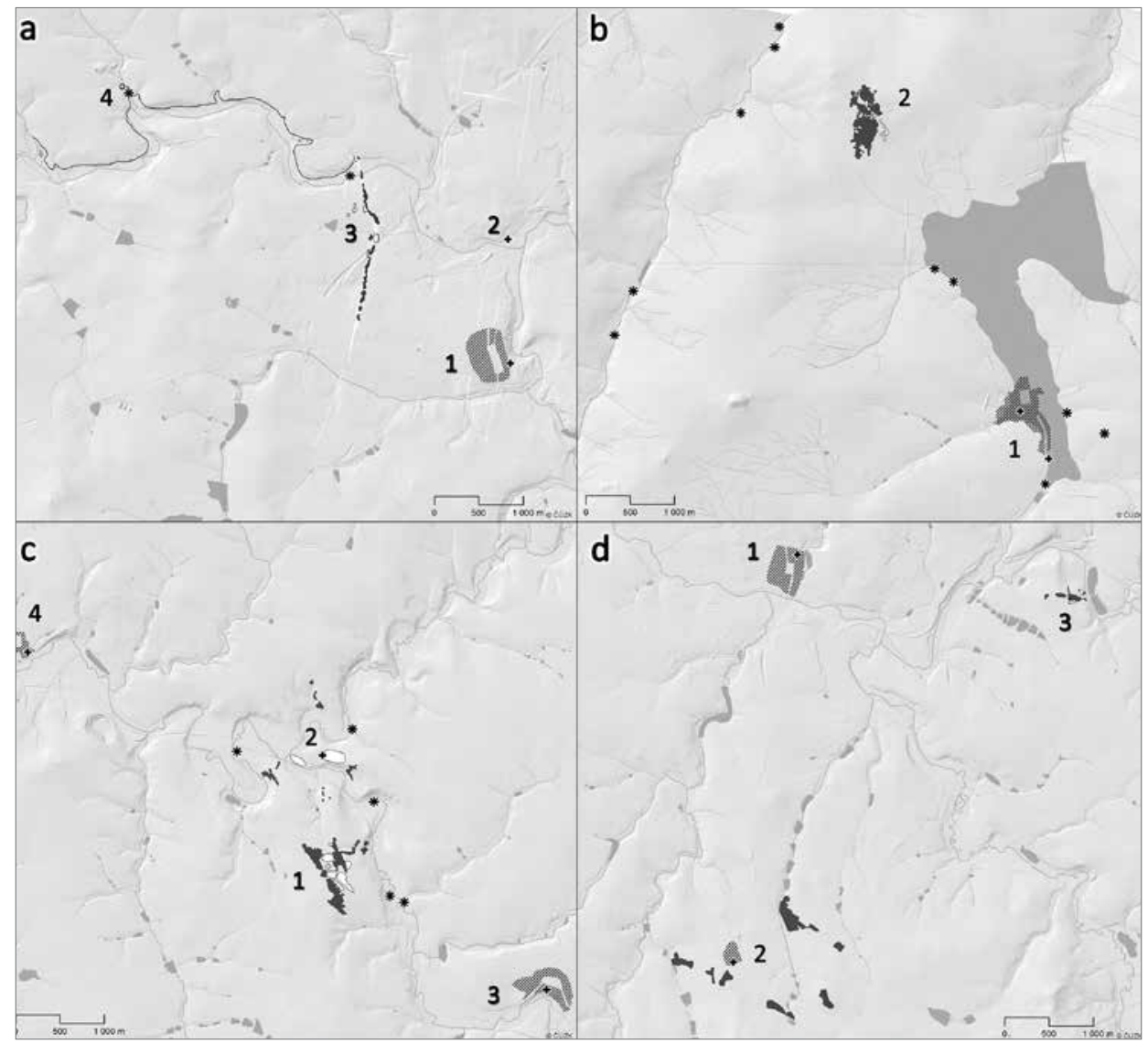

Obr. 3. Výběr lokalit se vztahem montánního areálu a př́slušného ekonomického (správního) centra. Jihlava (a): 1 - městské jádro, 2 - kostel sv. Jana Křtitele, 3 - hornická aglomerace Staré Hory (zvýrazněné plochy šachet a domů), 4 - motte a hutniště při dolním toku Bělokamenského potoka a Rantířovský př́íkop (černě). Př́ísečnice - Kremsiger (b): 1 - zaniklé město Př́ísečnice, 2 - montánní areál Kremsiger. Buchberg - Stříbrné Hory (c): 1 - předpokládané místo kaple, 2 - kostel sv. Markéty v prostoru zaniklého hornického sídliště Herliwinberg, 3 - Přibyslav, 4 - Pohled. Havlíčkův Brod a Mittelberg (d): 1 - Havlíčkủv Brod (jádro), 2 - kostel sv. Kříže ve stejnojmenné vsi, 3 - sídliště na k. ú. Termesivy. Tmavě šedě - montánní reliéf (výběr), černě lemovanou bílou plochou - sídelní relikty, bíle - průběh žil, hvězdička - hutniště, křížek - kostel. Podkladová data terénního reliéfu ČÚZK. Podkladová data pro vodstvo Výzkumný ústav vodohospodářský T. G. Masaryka.

Abb. 3. Auswahl an Fundstätten mit Bezug zu einem Montanareal und einem dazugehörigen wirtschaftlichen (administrativen) Zentrum. Jihlava (a): 1 - Stadtkern, 2 - Kirche St. Johannes der Täufer, 3 - Bergbauagglomeration Staré Hory (hervorgehobene Flächen - Schächte und Häuser), 4 - Motte und Verhüttungsanlage am Unterlauf des Baches Bělokamenský potok und Graben von Rantířov (schwarz). Př́sečnice - Kremsiger (b): 1 - Stadtwüstung Př́ísečnice, 2 - Montanareal Kremsiger. Buchberg - Stř́ibrné Hory (c): 1 - angenommener Ort der Kapelle, 2 - Margaretenkirche im Raum der Bergbausiedlungswüstung, 3 - Přribyslav, 4 - Ansicht. Havlíčkův Brod und Mittelberg (d): 1 - Havlíčkův Brod (Kern), 2 - Heiligkreuzkirche im gleichnamigen Dorf, 3 - Siedlung im Katastergebiet Termesivy. Dunkelgrau - Montanrelief (Auswahl), schwarz umsäumte weiße Fläche - Siedlungsrelikte, weiß - Verlauf der Adern, Sternchen - Verhüttungsanlage, Kreuz - Kirche. Basisdaten des Geländereliefs Tschechisches Amt für Landesvermessung und Kataster. Basisdaten für Gewässer T. G. Masaryk-Forschungsinstitut für Wasserwirtschaft.

V polovině 16. století přebírá tuto štafetu Jáchymov a těžiště produkce barevných a drahých kovů se v českých zemích ze starých rudních center českého vnitrozemí definitivně stěhuje do jiných oblastí, mezi kterými vynikají zejména Krušné hory.

U lokalit s bezprostřední vazbou na montánní areály lze konstatovat, že archeologické poznání hornictví vrcholného středověku spočívá dosud do značné míry na výzkumu větších hornických sídlišt' (viz kapitoly 3.2.2 a 3.2.3). Společným rysem těchto areálů je existence hornických 
sídlišst v blízkosti těžby. Terénní reliéf vypovídá o značné intenzitě dobývání a v hmotné kultuře nechybí doklady vyššího životního standardu.

Centralita hornických sídlišt' je z hlediska klíčových funkcí (zásobování, trh, farnost, administrativním zázemí) zpochybnitelná. Centrální roli hrála spíše města či kláštery a v některých saských revírech hrady. Charakteristicky jsou také jako centra oblastí zmiňována soudobými písemnými prameny pouze města. I velká hornická sídliště fungují jen v blízkosti měst. Jmenujme sousedství Starých Hor a Jihlavy, střediska Kremsiger a Př́sečnice (obr. 3b) či řady hornických sídlišt' kolem Havličkova Brodu (obr. 3d; Rous 2003). Centrální roli mohla hornická sídliště převzít, pokud se v málo urbanizovaných oblastech sama transformovala $\mathrm{v}$ město, což bylo spíše výjimečné (Freiberg, Kutná Hora, Kašperské Hory, snad Bleiberg na návrší Treppenhauer). Na druhé straně je třeba připomenout ve 13. a 14. století právo nově zřízených hornických sídlišt' na „svobodný trh“ (Tomaschek 1897), nebo později práva trhu předcházející povýšení na město (např. Krásno ve Slavkovském lese, Tomíček 2007, 102). Stejně tak není jasné, jaké byly vztahy hornických sídlišt' a měst $\mathrm{v}$ samém počátku těžebních aktivit.

Těžko najít znaky, které by tyto centrální lokality kvalitativně odlišovaly od méně významných sídlišt'. Výjimečný je val a prríkop na lokalitě Treppenhauer snad signalizující přerod v město. Určitou indicií významu jsou, jakkoliv stručné a sporadické zmínky v písemných pramenech, jejichž četnost je však lokálně diferencovaná (vyšší je např. v Sasku a na Havlíčkobrodsku). Množství doložených domů může být důsledkem delší existence, a nikoliv velikosti sídliště. Větší, resp. významnější sídliště mívají někdy organizovanější půdorys (náznak pravoúhlého uspořádání staveb ve středisku Kremsiger, ulicové uspořádání na lokalitě Treppenhauer, ale také na lokalitě Cvilínek). Většinou se však jedná o univerzální řazení domů podél dolů. Výskyt městských forem staveb (domy se zahloubenou částí) se zdá být na hornických sídlištích v českém a saském prostoru všeobecný bez ohledu na jejich význam. Lze ovšem uvažovat i o tom, že řada dalších hornických sídlišt' nebyla zatím nalezena právě proto, že byla tvořena méně nápadnými nadzemními domy.

\subsubsection{Středověké velkoprovozy primo provázané s městy}

Mezi nejstarší důlní areály, které si v dobovém měřítku zaslouží označení velkoprovoz, tedy rozsáhlejší komplexní provoz zahrnující vedle dolů i zpracovatelské a hutnické areály a sídliště (Hrubý 2014), patři na Českomoravské vrchovině jihlavské Staré Hory (obr. 3a; Hrubý 2011). Na Havlíčkobrodsku je to středisko Buchberg (obr. 3c; Hrubý a kol. 2016; Derner-Hrubý 2018, 215, 218). Jižně od Brodu lze určitě jmenovat také podnik Mons Medium, známý též jako Mittelberg (obr. 3d), který je zmíněn v listině olomouckého biskupa Bruna z 20. října 1256 (CDB V/1, 164 č. 90). Toto středisko patřilo s odhadovanou rozlohou až okolo 100 ha k největším v regionu. Samotné důlní areály jsou archeologicky nedatované a povrchové průzkumy byly prováděny v orných plochách mimo relikty důlních pracovišt'. Soubory fragmentární keramiky patří do 13. až 14. století a lze je vztáhnout $\mathrm{k}$ existenci hornického sídliště v době prosperity (Rous 2001, 67-69, 76; 2004, 50-51). Do této skupiny patří i Kremsiger (Lissek a kol. 2014; Bohdálek a kol. 2017; Derner 2018).

\subsubsection{Středověké velkoprovozy bez přimé vazby na města}

Specifické postavení z hlediska vzniku blízkého horního města zaujímají důlní střediska v saském i českém Krušnohoří, např́ílad Treppenhauer (Schwabenicky 2009) nebo Havirna u Štěpánova nad Svratkou (obr. 4c; Doležel-Sadílek 2004). Problematické je, nakolik lze velká důlní střediska bez skutečných horních měst v jejich blízkosti automaticky považovat za lokální centra hornických revírů. Faktem je, že tyto ikonické lokality stojí z hlediska podílu na správním a organizačním podílu na řízení důlní činnosti někde mezi městy, která představují zřetelně odlišnou kvalitu právní, správní i urbanistickou, a mezi dalšími, zdánlivě méně významnými hornickými sídlišti, od nichž je ale většinou nelze ostře oddělit, nemluvě o komplikacích daných srovnáváním různě intenzivně prozkoumaných lokalit. 


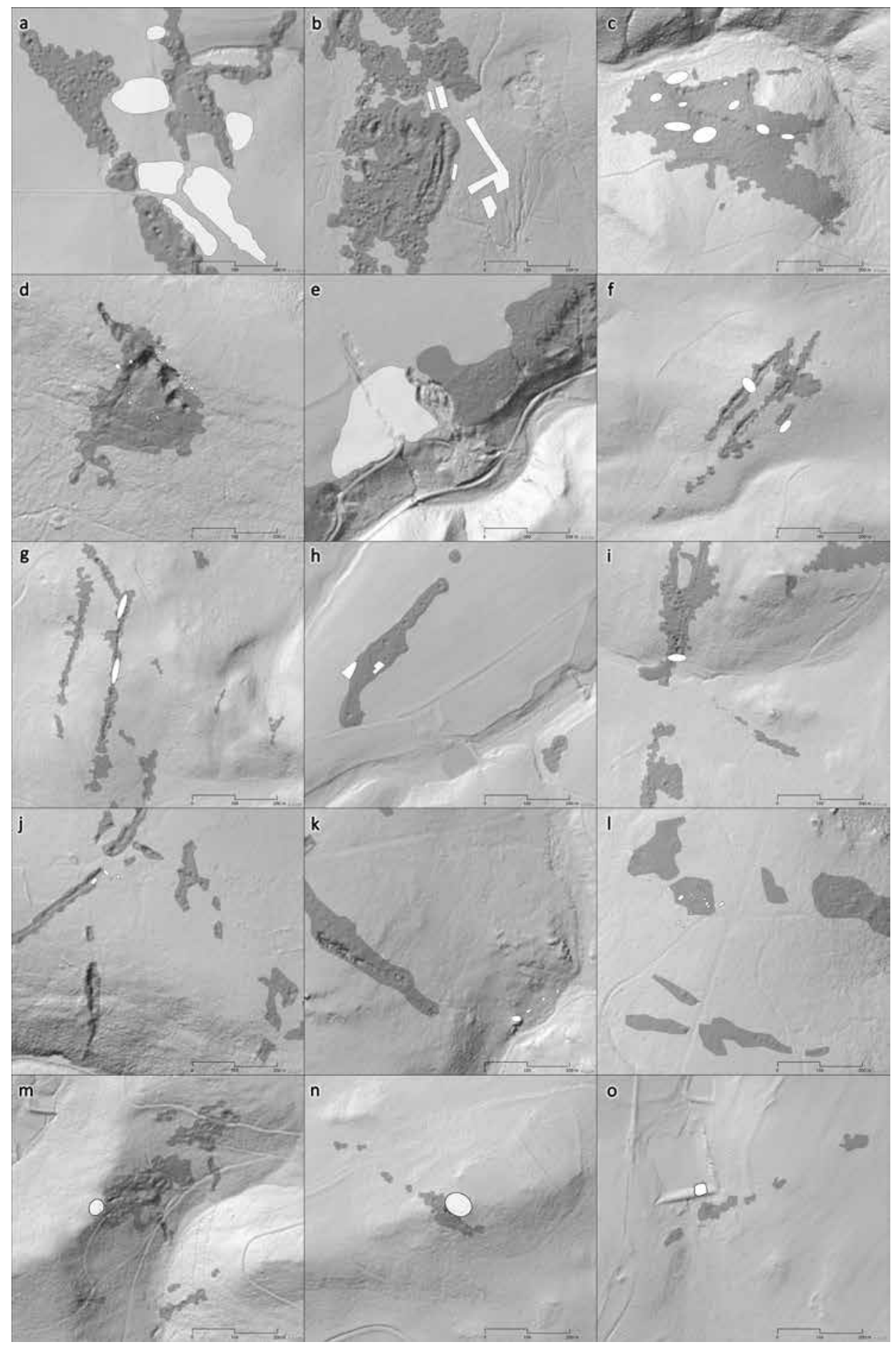


Obr. 4. Výběr lokalit $s$ bezprostředním vztahem montánního reliéfu a sídelních dokladů. Lokality interpretované jako velkoprovozy: Utín - Buchberg (a), Přísečnice - Kremsiger (b), Štěpánov nad Svratkou - Havírna (c) a možná i Zlaté Hory Erlitz (d) a Klínec (e). Lokality interpretované (spíše) jako maloprovozy: Kometa (f), Havírky (g), Vrbice - Hory (h), Borotice - Kozí Hory (i), Pískovec - Schwimmiger (j), Podlesí - Glücksburg (k), Mílov - Mückenberg (l). Lokality s doloženým opevněním v kontaktu s těžebním nebo hutnickým areálem: Krupka - Loupežný (m), Plánička - Stříbrník (n), Černov Cvilínek (o). Podkladová data ČÚZK.

Abb. 4. Auswahl an Fundorten mit unmittelbarem Bezug eines Montanreliefs mit Siedlungsbelegen. Als Großbetriebe interpretierte Fundorte: Utín - Buchberg (a), Př́ísečnice - Kremsiger (b), Štěpánov an der Svratka - Havírna (c) und vielleicht auch Zlaté Hory - Erlitz (d) und Klínec (e). (eher) als Kleinbetriebe interpretierte Fundorte: Kometa (f), Havírky (g), Vrbice - Hory (h), Borotice - Kozí Hory (i), Pískovec - Schwimmiger (j), Podlesí - Glücksburg (k), Mílov - Mückenberg (l). Fundorte mit belegter Befestigung und Kontakt zu einem Abbau- oder Hüttenareal: Krupka - Loupežný (m), Plánička - Stř́ibrník (n), Černov - Cvilínek (o). Basisdaten Tschechisches Amt für Landesvermessung und Kataster.

\subsection{Malé těžební či zpracovatelské areály (maloprovozy)}

Budeme-li pro začátek opět vycházet ze situace 13. a 14. století na Českomoravské vrchovině, tak aktuální montánně archeologický výzkum zde prosazuje, zčásti nejspíš oprávněně, označení maloprovoz. Ten by měl být spíše krátkodobý a vázaný na těžbu menších nalezišt'. Zároveň některá z komponent může chybět, zpravidla sídliště, popřípadě hutniště. Takovým př́íkladem je jeden ze zkoumaných menších areálů u České Bělé (Hrubý a kol. 2014, 69-97). Rovněž důlní a zpracovatelské centrum Cvilínek na Pelhřimovsku (obr. 4o) patří navzdory reprezentativnímu spektru nálezů ve srovnání s jihlavskými Starými Horami, středisky Buchberg na Havlíčkobrodsku, ale i Kremsiger v Krušných horách, spíše ještě do kategorie maloprovozů (Hrubý a kol. 2012). Dobovými maloprovozy byly nejspíš i areály u Opatova a Vyskytné na hranici Pelhřimovska a Jihlavska. Do této kategorie lze zařadit i aktuálně zkoumanou lokalitu u Koječína na Havlíčkobrodsku, kde se průzkum na detekci hornického sídliště zatím nesoustředil, ale jeho existence se důvodně předpokládá (Hrubý 2017, 3-8, 11, 13, 15-17). Archeologický obraz obou typů provozů se však nemusí př́liš lišit. Formulované schéma je nutno brát jako zjednodušující, realita byla pestřejší a ostré hranice mezi kategoriemi důlních areálů nejsou.

Vznik maloprovozů byl předurčen rudními ložisky menšího rozsahu, klíčová pro navazující úpravu rud byla i blízkost a četnost vodních toků. Typický pro úpravny a hutě ve středověkém maloprovozu je průnik dobyvatelného zrudnění a vodního toku, doložený na lokalitách Čejkov, Cvilinek a Chrástov na Českomoravské vrchovině (Hrubý a kol. 2014, 157) nebo Glücksburg u Potůčků v Krušných horách (Schneiderwinklová a kol. 2018 v tisku). V podobné situaci se nacházely hutnický a těžební areál Kreuziger či areál u štoly Goldloch na Černé vodě ve východním Krušnohoří. V druhém případě se patrně jednalo o osamocenou kovárnu u ústí štoly, což lze považovat za minimální infrastrukturu nezbytnou k provozu dolů (Crkal 2018). Pozůstatky drobných provozů bez zahloubených staveb mohou být kulturní vrstvy u dolů na Vysokém kameni (Crkal-Derner 2018). Stejně však platí, že úpravny rud nemusely vzniknout u každého těžebního areálu, ale mohly se koncentrovat na vhodných místech s vodními zdroji a obsluhovat více těžebních areálů v bezprostředním okolí.

Jako typické příklady lze uvést i sídliště na Příčné hoře u Zlatých Hor (obr. 4d; Večeřa-Večeřová 2006), lokalitu Klínec (obr. 4e; Richter 1981), lokality Havírky (obr. 4g; Fröhlich-Kurz 1980) a Kometa na Písecku (obr. 4f; Fröhlich 1992), Termesivy (Rous 1998), Nový Knín/Borotice (obr. 4i; Doležal-Korený-Kypta 2004), Hory/Vrbice (obr. 4h; Starý-Šanderová-Tomášek 2007; Doležel 2016) či Stříbrník u Pláničky na Klatovsku (obr. 4n; Červený 2007). Archeologicky se projevují menším množstvím artefaktů, ale obvykle i menším rozsahem ploch, ze kterých tyto nálezy pocházejí. Některé z nich mohou být po dalším výzkumu reinterpretovány jako lokální centra či velkoprovozy. Zatímco předchozí typ lokalit byl chronologicky jasně determinován, o drobném zázemí lze naopak říci, že je běžné ve středověku i v mladších obdobích. 


\subsection{Ohrazení v montánních areálech: výrazný rys nebo samostatný druh lokalit?}

Specifickým rysem je u hornických, zejména středověkých areálů ohrazení. To je v některých případech dokonce nejmarkantnějším sídelním dokladem. V první řadě je třeba rozlišovat mezi celými ohrazenými centry včetně přilehlých sídlišt' na straně jedné a mezi existencí menších opevněných bodů v areálech (Motte, Kleinburg, Wehranlage, Chateau). V české literatuře se vžilo označení hornické hrádky. Jsou obvyklou součástí organizační struktury středověkého hornictví (Schwabenicky 2009, 216-223). Rozdílná je jejich forma, velikost, architektura a vybavení, výzbroj, opevnění, popřípadě důraz na rezidenční funkce. Hrádky se vyskytují zpravidla $\mathrm{u}$ dolů $\mathrm{s}$ hutěmi a sídlišti, tj. tam, kde lze tušit významnější lidský i materiální potenciál. Byly zakládány často s důrazem na co největší blízkost $\mathrm{k}$ těmto areálům, a to i za cenu, že jsou tím ignorována i ta nejzákladnější vojenská a strategická pravidla umístění v terénu. Kromě lokality Burgstedt u Clausthal-Zellerfeld z 12.-14. století (Schwabenicky 2007, 139) patří do této skupiny i lokalita Brandes en Oisans ve francouzských Alpách, kde na skalním suku nad důlními pracovišti a sídlištěm vznikl menší kruhový hrádek. Uvést můžeme i zaniklý opevněný areál Blankenrode, v jehož rámci byl na východním okraji vybudován ještě samostatně hájitelný opevněný bod typu motte (Hucker 1984). Vazba na dolování zde však není bezprostřední, i když v okolí se rýžovalo zlato. Hrádek vyspělých stavebních forem vznikl také u hornického sídliště na lokalitě Birkenberg na jižním břehu potoka v údolí Möhlintal v jižním Schwarzwaldu (Fröhlich-Steuer 2002). V saském Podkrušnohoří je třeba znovu poukázat na stř̌edověký důlní podnik Fürstenberg na lokalitě Hohenforst, kde na severovýchod od sídliště obehnaného valem vzniklo tvrziště charakteru motte. Opevnění tohoto druhu se nalézá i poblíž důlních pracovišt' v poloze Ullersberg u obce Wolkenburg (Schwabenicky 2007, 131-136).

Na Jihlavsku se v údolí dolního toku Bělokamenského potoka v blízkosti menších těžebních areálů a $\mathrm{v}$ sousedství středověkého náhonu nalézá malé motte, k němuž se váže pojmenování Burgstadel. U něho se nalézá i struskoviště a zlomky mlecích kamenů (Malý a kol. 2007). Na Havlíčkobrodsku u Bartoušova nalezneme na východním břehu Šlapanky v lese $U$ hornických domků důlní tah, který na protějším západním břehu doplňuje další těžební areál a malé tvrziště v poloze Poustevnický rybník (Rous 2001, 66). Na Pelhřimovsku patř́ mezi objekty tohoto druhu Cvilinek, kde byl archeologicky zjištěn uzavřený příkop. Stratigrafie naznačují vznik v místě původně nehrazeného sídliště v mladší fázi lokality (Hrubý a kol. 2012, 381-382).

Otázkou dalšího bádání zůstává role oválných ohrazení v rámci montánních areálů Krupka/Loupežný (Derner-Lissek 2018 v tisku; Klusáčková 1981) a Střibrník u Pláničky (Červený 2007). V obou případech navazuje $v$ terénu poměrně dobře zachované ohrazení přímo na důlní pole. V krupeckém př́ípadě se na základě geologických analýz zdá, že převládajícím získávaným kovem byla měd', což poněkud kontrastuje s ustálenou představou ohrazených areálů jako průvodních objektů při těžbě drahých (regálních) kovů.

Za současného stavu poznání se zdá, že ohrazené areály jsou průvodním jevem středověkého hornictví 13. a 14. století a v mladším období se téměř nevyskytují. Otázkou dalšího bádání zůstává, jakou roli pak tato opevnění hrála v kontextu tří navržených typů lokalit. Není samotný výskyt ohrazení projevem alespoň minimální centrality? Mělo smysl budovat ohrazení u spíše krátkodobých areálů, popř́ípadě maloprovozů?

\subsection{Hornická centra mladšího typu}

Během výzkumu v rámci projektu ArchaeoMontan 2018 se v západním Krušnohoří ukázal dramatický rozdíl mezi rozsahem hornické činnosti ve středověku a v novověku. V části krajiny mezi Potůčky, Božím Darem, Jáchymovem a Merklínem bylo zjištěno mnoho sídelních dokladů ve vazbě na montánní relikty, nicméně i přes jistou potřebnou opatrnost se domníváme, že se v této ložiskově velmi významné části Krušnohoří až do počátku novověku nevytvořily podmínky pro existenci centrálních hornických areálů. Prozatím předpokládáme, že středověké hornictví se zde bez tohoto typu lokalit obešlo bud' díky svému malému rozsahu (resp. extenzivnímu 
charakteru) hornické činnosti, nebo z jiných důvodů. Za lokální centra hornické činnosti lze považovat až renesanční města zakládaná ve 30. letech 16. století (Horní Blatná, Boží Dar), anebo procházející v této době razantním rozvojem (Jáchymov, Abertamy, Pernink). Nabízí se proto otázka, jak se svou funkcí liší od starších lokálních center a co tyto rozdíly říkají o vývoji vztahu hornictví a osídlení.

U měst založených v 16 . století lze pozorovat opuštění přímé vazby na těžební areály. Toto tvrzení spíše neplatí pro Jáchymov a do určité míry i Abertamy, protože zde nebylo kvůli přítomnosti rudních žil v zásadě ani teoreticky možné se těžebním areálům vyhnout. Poloha Horní Blatné a Božího Daru však umožnila jak výrazné uplatnění ideových urbanistických zásad (Hanzlík 2013), tak i rozvinutí jejich hospodářského zázemí v optimální vazbě na intravilán. Celková koncepce obou lokací již pravděpodobně počítala s dlouhodobou existencí schopnou hospodářsky zajistit hornickou činnost a snad i překonat propady v těžební konjunktuře. U všech zmíněných měst počítáme rovněž s vazbou na významnější cesty, která byla důležitou podmínkou hospodářského fungování města.

\subsection{Syntéza typologie lokalit}

$\mathrm{Z}$ vyčleněných typů hornických areálů s doklady sídel je zřejmé, že některé $\mathrm{z}$ nich lze považovat za opakující se typ a jiné zřejmě existovaly jen za určitých podmínek, at' už chronologických, majetkoprávních či ložiskově geologických. Načrtnutou typologii je proto nutné brát jen jako orientační.

Pro další úvahy je podstatná formulace kroku vedoucího k přesnější definici konkrétních hornických areálů.

Intenzitu historické hornické činnosti lze kriticky odhadovat podle rozsahu terénních reliktů, přičemž v některých př́ípadech dobu rozmachu studovaných areálů chronologicky upřesnují písemné prameny. Tyto areály lze nyní teoreticky posuzovat podle vytvořeného schématu kategorií, což může vést $\mathrm{k}$ jejich konkrétnější a přesnější interpretaci v regionálních i nadregionálních souvislostech. Zejména centrální lokality měly nejspíš svoji spádovou oblast, kterou lze někdy odvodit z písemných pramenů. Podstatný je však chronologický a technologický aspekt, což generuje poslední klíčovou otázku.

\section{Otázka existence nadregionálně univerzálních vývojových trendů}

Stejně jako se opakují jisté rysy na úrovni lokalit či montánních areálů, vykazuje i vývoj mnoha revírů společné trendy. Již dříve byly formulovány etapy i příčiny rozmachu a úpadku těžby v různých regionech. Podstatný je však širší pohled, tzn. formulace jednoduchých kritérií, podle kterých lze porovnávat vývoj v různých oblastech. Různé fáze vývoje hornické činnosti, jejichž výčet následuje v další části, je však třeba uvést poukazem na okolnosti, které je mohly ovlivnit. Byly to především:

a) dopravní dostupnost - vazba na sít komunikací, at' už lokálních, regionálních, či nadregionálních;

b) sídelní a majetkové poměry v dobách vrcholů a konjunktur hornictví v daném regionu;

c) převládající typ zrudnění (typy rudních těles, kovnatost, hloubky, dobyvatelnost, přítok důlních vod);

d) právní a hospodářské poměry epoch, v nichž hornictví v daném regionu zažíá první doložitelný rozmach;

e) převládající krajinný reliéf daných oblastí a dostupnost vodních zdrojů. 


\subsection{Rané písemné zmínky o revírech, jejich využitelnost a charakter}

Jako celek bývají první zmínky nejvíce charakteristické svojí náhodností. Přes svůj zpravidla chybějící kontext však představují pro těžbu v dané oblasti či revíru pevný datovací bod ante quem. Podíváme-li se na charakter a lokalizaci raných zmínek pro daný revír, může výsledný obraz indikovat jisté trendy. Užitečná bývá zejména jejich lokalizace naznačující prostorový rozsah užívaného území, cenný zejména $\mathrm{v}$ situaci, kdy o počátcích těžby daném v revíru dosud chybí archeologické poznatky.

Písemné zmínky mohou prozrazovat i sociální kontext, resp. angažmá různých společenských vrstev. Například na Českomoravské vrchovině byli ve 13.-14. století z principu téměř jedinými provozovateli dolů měšt’ané. Výjimečně se jako spoludržitelé propůjčky mohou objevit zástupci klášterů. To je př́́klad propůjčky z 23. října 1272, kterou přijali těžaři Werner Loting a opat želivského kláštera Marsilius od trojice urburéřů pro Čechy a Moravu (CDB V/2, 320 č. 681). Zdaleka nejvýznamnějším dokumentem je ale propůjčka skupině těžařů z 25 . října 1258 vydaná ve Šlapanově na Havlíčkobrodsku. V ní se jmenují doly Iegerberch, Vberschar, Hertwigesberch, Breitbartesberch, Scubelerberch, Helmerichesberch, Buchberch Juvenis et Buchberch Antiquus, Lettenberch, Clophurberch, Hohalde, Haberberch, stollo Vribergeri, stollo Cunradi a Gotesgabe (CDB V/1, 267 č. 167). V tomto prrípadě jde o ucelenou oblast revíru provozovanou centrálně, př́ípadně rovnou o samostatný revír.

Rané zmínky k části západního Krušnohoří zhruba mezi Nejdkem a Jáchymovem začínají rokem 1273 s vazbou na kolonizaci podhůří (tzv. hroznětínský újezd) tepelským klášterem (Trnka 2016, 258). Teprve k roku 1340/1341 se váže zmínka o cínových dolech, opět s vazbou na klášterní poddané (Rojík 2000,143). K roku 1350 následuje zpráva o železnorudných dolech. Všechny mají společnou lokalizaci spíš do podhůří, i když prostorový záběr mohly mít větší, než dnes předpokládáme. Do vyšších partií Krušných hor, k lokalitě Schwimmiger/Pískovec však raná zmínka míŕí jen s malým zpožděním (Malina a kol. v tisku).

Ve východním Krušnohoří jsou př́ijemci nejstarších privilegií a aktéři sporů o doly či výnosy příslušníci šlechty (páni z Rýzmburka, Zvěst z Trmic, Koldicové, Šumburkové) a Osecký klášter (Derner-Lissek 2018 v tisku). Důlní podnikatelé, pronajímatelé a provozovatelé dolů z nižších sociálních vrstev se objevují v pozdějším období. Jsou to měštané poddanské Krupky či královské Kadaně, ale i osoby ze vzdálenějších oblastí. I zde, podobně jako v západním Krušnohoří, jsou první zprávy o dolování $(1302,1305,1339)$ za archeologicky datovanými, či důvodně předpokládanými počátky exploatace kovů výrazně zpožděny, v průměru o 50 let.

\subsection{Průzkumná etapa}

Prvním krokem k těžbě ložiska je jeho objevení, kterému mohlo podle okolností předcházet rýžovnictví. Pokud pomineme náhodně objevená ložiska, bylo objevení ložisek záležitostí různě početných skupin prospektorů spočívající spíše v odběru vzorků, případně s použitím ojedinělých technických mělkých děl (kutací jámy).

Po objevení ložiskově nadějného terénu začala druhá etapa - nalezení ekonomicky zpracovatelných surovin. Tady se dá již předpokládat zapojení většího, a v př́ípadě velmi nadějných lokalit skutečně velkého množství kutéřů, kteří mnohdy na rozsáhlých plochách nahodile hloubili kutací jámy, jimiž většinou dosáhli pouze skalního podkladu. Pozůstatky této etapy lze pozorovat na okrajích těžebních areálů. V př́ípadě neověření nadějného ložiska se může jednat o celý areál tvořený jen těmito pozůstatky. V tomto prŕípadě by bylo vhodnější mluvit pouze o kutacím areálu. Pokud byla tato etapa krátkodobá, neiniciovala vznik hornických sídel. V případě velkých a déle prospektovaných oblastí se mohla vyvinout krátkodobá sídla a zásobovací systém, poskytující kutéřum nářadí, potraviny a krmivo. 


\subsection{Raná exploatace a vżtahy $k$ sídelnímu a zemědělskému zázemí}

Velký význam pro staré hornictví měly hospodářské základy. Bez vazby na zemědělské zázemí se do určité míry mohla obejít jak extenzivní prospektorská činnost, tak i minimálně počáteční etapy dobývání v mnoha revírech, ale těžba většího rozsahu s nutností zavedení pevných pravidel již nikoliv. V rané fázi exploatace sekundárních ložisek (zlata, cínu) a železných rud se k místům těžby vztahují spíše zprávy s vazbou k zemědělské kolonizaci území. Jak zemědělské, tak těžební areály byly v úzkém vztahu k sídelním strukturám, většinou v nižších nadmořských výškách a širších údolích.

Výškový a geografický dosah ilustrují i lokalizace starých dolů v nadmořských výškách kolem $1000 \mathrm{~m}$. Důležitý v této souvislosti mohl být i řidší vegetační pokryv, který usnadňoval prospekci. Jako prríklad lze uvést jesenické Starohoři i s osídlením (Večeřa-Večeřová 2006), Vysokou (zatím bez osídlení) a Soukennou s vazbou až na Horní Město (Večeřa 2016).

\subsection{První fáze těžby v tělesech primárního zrudnění ve velkém}

Klíčovou fází rozvoje každého revíru bývá jeho „první zvolání“, respektive první etapa těžby primárního ložiska v takové míře, která si vynutila vybudování alespoň základní infrastruktury pro těžbu, úpravu a hutnické zpracování. Důležité je rovněž vytvoření nutného sídelního zázemí (viz kap. 3). Významnou roli zde hrál druh těžené suroviny. Zatímco například extenzivní a regálně neomezovaná těžba železných rud nezanechala ve středověku a v raném novověku téměř žádnou stopu v písemných pramenech, těžba regálních drahých kovů s sebou nesla snahu držitele regálu o dohled spojenou s odrazem v písemných pramenech a někdy i tendenci k „horečkám“.

Těžba probíhala většinou etapovitě. První etapou bývalo rychlé vydobytí nejlépe dostupných rudních partií ložisek v hloubkách do prvních desítek metrů. Nejsnáze tavitelné rudy se nacházely v oxidační zóně, nejbohatší však v zóně cementační. Práce proto směřovaly co nejrychleji do cementační zóny ložiska. Druhá etapa zpravidla následovala v souvislosti s vyřešením odvodnění hlubších partií ložisek. Ke zvládnutí přítoku důlních vod přispívala až ražba štol, ale efekt přineslo teprve jejich propojení s dobývkami. K tomu však v mnohých dolech z řady důvodů nakonec ani nedošlo, nebo to bylo provedeno př́iliš pozdě. Svou roli sehrála i celková morfologie terénu. Například v Jáchymově bylo díky hlubokým údolím odvodnění nižších žilných partií jednodušší než na Božím Daru nebo v celkově plochém reliéfu Českomoravské vrchoviny.

Značný vliv měl i hydrologický potenciál. Energeticky využitelné vodní zdroje, které jsou například na Českomoravské vrchovině ve srovnání s Krušnými horami i s Jeseníky jednoznačně limitované, předurčovaly i omezená území, kde mohly být zřizovány úpravny a hutě. Slabší vodně energetický potenciál krajiny ještě mohl dostačovat dobově malému objemu a tempu důlní činnosti, jakkoliv může rozsah hornické činnosti 13. století působit velkolepě. Nemohl však už vyhovovat objemu a tempu těžby rud, jaké vyžadovala Evropa 15./16. až 18. století, ani energetickým nárokům těžních a úpravnických strojů té doby, s nimiž se vodou poháněná zařízení 13. století nedala srovnávat. Jinými slovy, příčinou toho, proč se na Vysočině nedá v tzv. druhém období předprůmyslového hornictví hovořit o obnově těžby, ale jen o pokusech, nemusela být jen vytěžená rudní ložiska, nýbrž i omezené vodní zdroje. O ty se kromě toho musel důlní „průmysl“ dělit s rozvinutou a hustou zemědělskou i urbánní sídelní infrastrukturou, a to mnohem více než např́íklad v prakticky neosídleném vnitřním pásmu západního Krušnohoří.

V naznačených souvislostech lze uvést i jáchymovskou otázku. Sehrála u pozdního zahájení těžby zdejších bohatých stříbrných ložisek svou roli jejich lokalizace ve vyšších nadmořských výškách? Přidala se k tomu i komunikační odloučenost jáchymovského údolí, kdy tradiční tranzit přes krušnohorské hřebeny vedl až na výjimky (Malina a kol. 2018 v tisku) spíše východně (Př́isečnicko) či západně (Nejdek) od Jáchymova? 
Archeologicky je možné první zvolání zachytit zpravidla jako větší množství archeologických nálezů vázaných na důlní areál tam, kde zároveň chybí doklady mladší fáze. Nejobtížnější je rozhodnout, $s$ jakou intenzitou tato první fáze probíhala. Písemné prameny často přinášejí zmínky o štole či jamách, nebo dokonce o opuštěných (starých) dílech. V revírech s výraznou novověkou fází je šance zachytit průkazné relikty středověké těžby jdoucí nad rámec pouhého konstatování přítomnosti mimořádně obtížné. Na druhé straně není rozsah prací v rámci prvního zvolání pro naše otázky až tak podstatný.

Klíčovou roli ve struktuře archeologicky zásadního sídelního zázemí hrály dobové poměry, v nichž doly vznikaly a pracovaly. Jestliže u dolů určité velikosti a délky provozu vznikaly ve 13. století často rozsáhlá sídliště, pak v 16. či 17. století ke vzniku podobných hornických osad na podobně velkém dole již téměř jistě nedošlo. Důlní pracovníci byli v té době již většinou součástí obyvatelstva na předměstích, popřípadě obývali chudší profesní čtvrti v blízkých městech. Dramaticky rozdílné bylo rovněž užívání zdrojů dřeva. Ve 13. století bylo prakticky neomezené a volné, v 16. století, např́iklad podle důlních účtů z Kutné Hory či Horní Blatné, ale i z Jihlavy (Ladová 1960; Křepelková; Kubátová 1992; Vosáhlo 2009, 299-301), bylo už dřevo nedostatkovým a drahým materiálem.

\subsection{Fáze úpadku těz̆by}

$\mathrm{Z}$ archeologického hlediska jsou fáze úpadku důležité zejména tam, kde se jednalo o úpadek poslední, nenásledovaný další etapou s ještě větším rozsahem exploatace. Například u řady menších revírů, kde se těžba odehrála víceméně jen v 16. století, může archeologická situace nabídnout nepřevrstvené doklady nejen jednotlivých lokalit, ale i větší části celé navazující infrastruktury. Jiným př́íkladem je zakonzervování středověké těžby v andělskohorském rudním revíru, kde je dochováno asi $4,5 \mathrm{~km}$ středověkých důlních tahů, jen minimálně porušených novějšími průzkumnými díly (nikoliv těžbou).

\subsection{Obnova tě̋̌by: př́tomnost, četnost a význam obnovných fází}

Obnovné fáze jsou důležité především kvůli archeologickému potenciálu. Významné revíry měly svých „zvoláni““ zpravidla více, často zaměřených na odlišné suroviny. V této souvislosti vyniká zejména srovnání západního Krušnohoří a Českomoravské vrchoviny. Zde po skončeném období stř̌edověké konjunktury šlo spíše o pokusy, anebo nepřiliš úspěšné důlní podnikání, třebaže otevírání a provoz dolů např́íklad na starohorské dislokační zóně u Jihlavy v 16. až 17. století může působit napohled velkorysým dojmem (Vosáhlo 2009).

\section{Úrovně štol na Altenbergu ve Zlatohorském revíru}

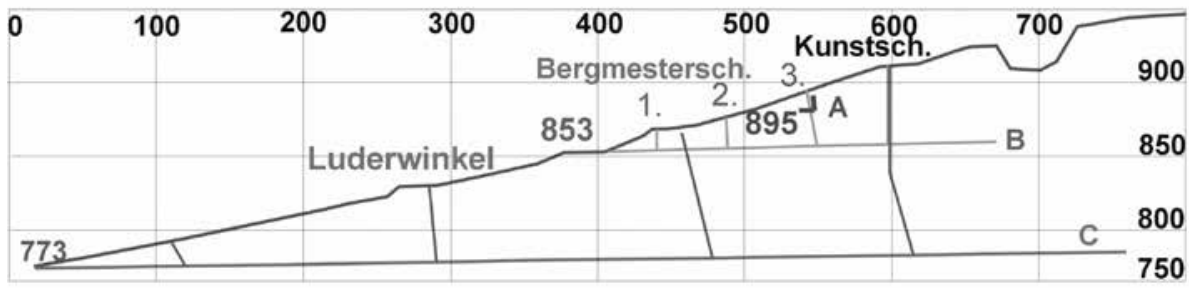

\section{A - krátká štola pod nejnižší důlní tah - hloubka $10 \mathrm{~m}$$$
B \text { - I. dědičná štola - (jihlavská naučení) }
$$$$
\text { C - II. dědičná štola - (správa vroclavským bisk.) }
$$

Obr. 5. Výškový sled odvodňovacích štol k montánnímu areálu na Příčné hoře u Zlatých Hor. Abb. 5. Höhenfolge der Wasserstollen zum Montanareal auf dem Berg Př́čná hora bei Zlaté Hory. 


\subsection{Výškový sled štol}

Za specifický společný rys mnoha revírů lze považovat výškový sled odvodňovacích (dědičných) štol. Jejich funkce byla klíčová zejména tam, kde byl zájem o dlouhodobější využívání ložiska. Nejstarší v každém sledu bývají štoly situované v nejmenší hloubce pod výchozem ložiska (obr. 5). V případě slibného vývoje těžby se zakládaly hlubší, a tedy i zpravidla delší štoly. V této části našich úvah mají štoly význam indikátoru kontinuity nebo etap těžby a do určité míry i technologické a finanční kapacity těžařů.

\subsection{Dolová pole: chronologie a četnost hlavních těžebních etap}

Pokud byly průzkum a těžba ložiska řízeny určenými pravidly, lze jejich odraz nalézt i v terénních pozůstatcích. Povrchové pozůstatky se kumulují do skupin, které mohou být specifické pro různé lokality, a to svojí délkou nebo i počtem a uskupením jednotlivých objektů, většinou jam (Večeřa 2008). V případě překryvu takovýchto vyčleněných úseků lze stanovit jejich relativní chronologii. Pokud charakter některých úseků odpovídá dobovým právním předpisům, lze se pokusit i o rámcové časové zařazení. Příkladem může být interpretace tvarově specifických „krupeckých poli““ podle báňského řádu z roku 1487, zvláště v historickém revíru Steinknochen (Večeřa-Večeřová 2013). Pro časové zařazení se jeví jako nejvýznamnější rozdíl vyměřování průzkumných polí a dolových měr podle středověkých báňských řádů, pro něž jsou typické skupiny tř́i nebo pěti jam, a novověkých báňských řádů, počínaje jáchymovským (annaberským), pro které jsou specifické dvojice jam (Večeřa 2013).

\section{Syntéza}

Na Českomoravské vrchovině byly již úspěšně řešeny otázky širší hornické a navazující sídelní infrastruktury. Budeme-li chtít podobné otázky řešit i jinde, je třeba brát ohled také na vývoj jednotlivých revírů. Např́íklad v zatím zkoumané části západního Krušnohoří jsou obdobné otázky pro středověkou fázi v zásadě téměř neřešitelné, a to i přesto, že prostorový dosah (ve smyslu nadmořské výšky) byl ve stř̌edověku i v novověku v zásadě totožný. Archeologický potenciál obou regionů se proto v otázce stř̌edověké infrastruktury výrazně liší. Otázka potenciálu je klíčová například pro archeologické možnosti výzkumu montánní krajiny Slavkovského lesa. I zde se dá předpokládat masivní rozvoj těžby a zpracování rud v 16. století, a je proto otázkou, do jaké míry a $\mathrm{v}$ jakých částech byly překryty možné starší středověké montánní relikty. Na druhé straně je západní Krušnohoří velmi důležité pro hornictví 16. století. Můžeme zde doložit zřejmě kompletní sídelní infrastrukturu od drobného zázemí na důlních tazích přes menší osady při vodních tocích a v blízkém zázemí těžebních areálů až po nově lokovaná města. Tato hierarchie přímo vybízí ke srovnání celé oblasti s jinými regiony.

Mezistupněm mezi západním Krušnohořím a Českomoravskou vrchovinou, pokud jde o nadmořské výšky i postup středověkého osídlení, je východní Krušnohoří. Proměnlivá dostupnost, úrodnost půd i dopravní infrastruktura podmiňovaly vznik nejrůznějších konstelací hornictví a zemědělského osídlení od čistě zemědělských enkláv přes smíšenou kolonizaci až k oblastem využívaným výhradně neagrárně (Derner-Hrubý 2018). Měřítkem intenzity středověké těžby stříbra a cínu je rozvoj měst Krupky a Přísečnice, spolu s hornickým sídlištěm Kremsiger v centru dvou hlavních hornických obvodů. V méně osídlených oblastech je hornictví doloženo až v novověku (revíry Hora Svaté Kateřiny a Vejprty). Na rozdíl od Českomoravské vrchoviny zažilo východní Krušnohoří významné období druhého zvolání spojené s další urbanizací a dosídlením. Svědčí to o nemalých zásobách stříbra a cínu ponechaných v tradičních středověkých hornických obvodech.

Další výzkum by neměl končit snahou o archeologické poznání na úrovni dílčích lokalit či montánních areálů. Některé z nich jsou si svým vývojem podobné, což dává jistou možnost interpretovat chybějící části jejich komplexního poznání pomocí analogicky využitých poznatků 
odjinud. Dobré analogie jsou důležité nejen v úrovni jednotlivých lokalit, ale i větších území s hornickou činností, at' už je budeme nazývat revíry, obvody či oblastmi.

Z praktického hlediska byla naší snahou lepší definice výzkumných otázek širšího významu. Správná definice typů lokalit a univerzálních fází umožňuje lepší průzkum u dosud málo zkoumaných revírů. Širší pohled na věc vyžadují jevy, jako je odlišný energetický potenciál regionu a jeho vliv na infrastrukturu v období po útlumu těžby anebo transformace hospodářství na jiné typy obživy. Chápeme-li hornické areály jako jednotku pramenné základny, at' už je jejich přesná definice jakákoli, je nutné uvažovat i o určitém uspořádání a univerzálním popisu toho, co se kde dochovalo a jaké historické a archeologické otázky lze vůbec řešit.

Studie vznikla při řešení projektu Udržitelný rozvoj kulturní krajiny a ochrana historických památek v zalesněném prostředí, kód projektu: TL02000111.

\section{Prameny}

CDB V/2: Codex diplomaticus et epistolarius regni Bohemiae V/2 (1267-1278) (Šebánek, J.-Dušková, S., edd.). Pragae 1981.

CDM V: Codex diplomaticus et epistolaris Moraviae V (1294-1306) (Chytil, J., ed.). Brunae 1850.

CIM II: Codex juris municipalis regni Bohemiae II. Privilegia královských měst venkovských v království Českém z let 1225-1419 (Čelakovský, J., ed.). Praha 1895.

ERMISCH, H., 1887: Das sächsische Bergrecht des mittelalters. Leipzig 1887.

TOMASCHEK, J. A., ed., 1897: Das alte Bergrecht von Iglau und seine bergrechtlichen Schöffensprüche. Innsbruck.

\section{Literatura}

BOHDÁLEK, P. a kol., 2017: Bohdálek, P.-Crkal, J.-Derner, K.-Kočár, P.-Lissek, P.-Kočárová, R.-Kyselý, R.-Šrein, V., Kremsiger 2016. Stav výzkumu středověkého hornického sídliště v Krušných horách - Kremsiger 2016. A state of the excavation at the medieval mining settlement in Krušné Hory (Ore Mountains, Czech Republic), Acta Rerum Naturalium 21, 111-124.

CRKAL, J., 2018: Středověké hutnictví a hamernictví na Přísečnicku - Mittellalterliches Hütten- und Hammerwesen. In: Derner, K., Středověké hornictví a hutnictví na Př́isečnicku ve středním Krušnohoří Veröffentlichungen des Landesamtes für Archäologie Sachsen. Band 68. ArchaeoMontan 5, 137-213. Dresden.

CRKAL, J.-DERNER, K., 2018: Sídlištní stopy na Vysokém kameni (Hohensteinu), k. ú. Dolní Halže. In: Derner, K., Stř̌edověké hornictví a hutnictví na Př́isečnicku ve stř̌edním Krušnohoří - Veröffentlichungen des Landesamtes für Archäologie Sachsen. Band 68. ArchaeoMontan 5, 385-387. Dresden.

ČERVENÝ, A., 2007: Historická těžba polymetalických rud u Pláničky na Klatovsku - Historische förderung von polymetallerze bei Planicka in der Nähe von Klatovy. In: Stř́brná Jihlava 2007. Studie k dějinám hornictví a důlních prací, 114-123. Jihlava - Brno.

- 2017: Vrcholně středověká hornická sídliště se zvláštním zřetelem k lokalitě Kremsiger (k. ú. Přísečnice). Diplomová práce, ulož. na FF UK, Praha.

- 2018: Hornické sídliště na Kremsigeru. In: Derner, K., Středověké Hornictví a hutnictví na Přísečnicku ve středním Krušnohoří - Veröffentlichungen des Landesamtes für Archäologie Sachsen. Band 68. ArchaeoMontan 5, 217-329. Dresden.

DERNER, K.-LISSEK, P., 2018, v tisku: Středověké hornictví v českém Krušnohoří. In: ArchaeoMontan 2018. Das Erzgebirge im Fokus der Montanarchäologie - Krušné hory v zájmu montánní archeologie, Arbeits- und Forschberichte der sächsischen Bodendenkmalpflege. Beiheft 32 (Smolnik, R.-Goryczková, N., edd.). Dresden - Loket.

DERNER, K.-HRUBÝ, P., 2018: Otázka zemědělství a potravinářské produkce zemědělských hornických komunit - Zur Frage der Landwirtschaft und Nahrungsmittelproduktion mittelalterlicher Bergbau kommunitäten, AH 43, 207-239. 
DOLEŽAL, D.-KORENÝ, R.-KYPTA, J., 2004: Archeologické nálezy z hornických pracovišt' v okolí Nového Knína, ASČ 8, 674-675.

DOLEŽEL, J., 2016: K těžbě stř́ibra na Horách Vrbických v 16. století, PV 57, č. 2, 197-248.

DOLEŽEL, J.-SADÍLEK, J., 2004: Středověký důlní komplex v trati Havírna u Štěpánova nad Svratkou. Příspěvek k dějinám těžby stř́bra v oblasti severozápadní Moravy ve 13. a 14. století. Výsledky průzkumu v letech 1990-2001, edice písemných pramenů. In: Těžba a zpracování drahých kovů: sídelní a technologické aspekty. Mediaevalia archaeologia 6 (Nováček, K., ed.), 43-119. Praha.

ERNÉE, M. a kol., 2014: Ernée, M.-Hrubý, P.-Malý K.-Tomášek, M.-Valkony, J., Raná exploatace exogenních akumulací zlata na Českokrumlovsku - Early exploitation of the secondary gold deposits by Český Krumlov, Acta rerum naturalium 16, 185-108.

FROLÍK, J.-TOMÁŠEK, M., 2002: Kutná Hora. Př́íspěvek archeologie k nejstarší topografii a komunikačnímu schématu města. In: Civitas et villa. Miasto i wieś w średniowiecznej Europie środkowej (Buśko, C.-Klápště, J.-Leciejewicz, L.-Możdzioch, S., edd.), 99-106. Wrocław - Praha.

FRÖHLICH, J., 1992: Ruční mlýny na rozemílání rudy na Kometě, Studie z dějin hornictví 22, 11-33.

FRÖHLICH, J.-KURZ, J., 1980: Středověké zlaté doly Havírky u Písku, Studie z dějin hornictví 10, 17-25.

FRÖHLICH, M.-STEUER, H., 2002: Burgen und Bergbau. Zum Abschluss der Grabungen an der ,Birchiburg" in Bollschweil-St. Ulrich, Kreis Breisgau-Hochschwarzwald. In: Archäologische Ausgrabungen in Baden-Württemberg, 203, 238-243. Stuttgart.

HANZLÍK, J., 2013: Město a jeho koncept. In: Proměny montánní krajiny. Historické sídelní a montánní struktury Krušnohoří, 76-81. Loket.

HÖSEL, G.-BREITER, K., edd., 1995: Mineral Resources Erzgebirge-Vogtland/Krušné hory Map 2: Metals, Fluorite/Barite - Occurrences and Environmental Impact - West. 1: 100000 - LfULG, Česká geologická služba. Praha.

HRUBÝ, P., 2011: Jihlava - Staré Hory. Archeologický výzkum středověkého důlního, úpravnického a obytného areálu v letech 2002-2006. Př́íspěvek ke studiu středověkého rudného hornictví. Dissertationes archaeologicae brunenses pragensesque 9 (Klápště, J.-Měřínský, Z., edd.). Praha - Brno.

- 2014: K periodizaci počátku rané exploatace drahých kovů na Českomoravské vrchovině - Zur Periodisierung des Beginns der frühen Ausbeute von Edelmetallen in der Böhmisch-Mährischen Höhe. In: ArchaeoMontan 2013. Krušná krajina - Erz(gebirg)landschaft - Ore landscape. Arbeits und Forschungsberichte zur sächsischen Bodendenkmalpflege. Beiheft 28 (Smolnik, R., Hrsg.), 147-155. Dresden.

- 2017: Nové průzkumy středověké montánní krajiny na Českomoravské vrchovině, Acta rerum naturalium 21, 1-20.

HRUBÝ, P. a kol., 2007: Hrubý, P.-Hejhal, P.-Malý, K., Montanarchäologische Forschungen in Jihlava-Staré Hory (Iglau-Altenberg, Tschechien), Zeitschrift für Archäologie des Mittelalters 35, 17-60.

HRUBÝ, P. a kol., 2012: Hrubý, P.-Hejhal, P.-Hoch, A.-Kočár, P.-Malý, K.-Macháňová, L.-Petr, L.-Štelcl, J., Středověký úpravnický a hornický areál Cvilínek u Černova na Pelhřimovsku, PA CIII, 339-418.

HRUBÝ, P. a kol., 2014: Hrubý, P.-Hejhal, P.-Malý, K.-Kočár, P.-Petr, L., Centrální Českomoravská vrchovina na prahu vrcholného středověku: archeologie, geochemie a rozbory sedimentárních výplní niv. Opera Universitatis Masarykianae Brunensis, Facultas Philosophica 422. Brno.

HRUBÝ, P. a kol., 2016: Hrubý, P.-Malý, K.-Milo, P., Archeometalurgie a geofyzika středověkých areálů zaměřených na produkci drahých kovů - Archäometallurgie und Geophysik mittelalterlicher, auf die Produktion von Edelmetallen ausgerichteter Areale, AH 41, 39-63.

HUCKER, B. U., 1984: Die untergegangene Bergstadt Blankenrode im Diemel-Eder-Kupfererzrevier: Beobachtungen zum Problem abgegangener Bergstädte. In: Montanwirtschaft Mitteleuropas vom 12. bis 17. Jahrhundert. Stand, Wege und Aufgaben der Forschung. Der Anschnitt. Beiheft 2 (Kroker, W.-Westermann, E., Hrsg.), 103-110. Bochum.

ILAVSKÝ, J.-SATTRAN, V., 1980: Vysvětlivky k metalogenetické mapě ČSSR 1 : 500000 . Ústřední ústav geologický. Praha.

JANGL, L., 1979: Edice České horní právo 4. Báňské řády. Příbram.

KLUSÁČKOVÁ, V., 1981: K problému opevnění v Krušných horách - Zum Problem einer Befestigung in Krušné hory (Erzgebirge), AH 6, 63-70.

KOŘAN, J., 1955: Naše báňská technika za feudalismu. In: Sborník dějin přírodních věd a techniky II. Rozpravy Národního technického muzea, 5-52. Praha.

KŘEPELKOVÁ, A., 1957: Příspěvek k hospodářským a sociálním dějinám kutnohorských havířů na sklonku XV. a v první polovině XVI. století, Středočeský sborník historický 1, 67-83.

KUBÁTOVÁ, L., 1992: Nejstarší dolové účty Horní Blatná. Edice faksimilií. Sv. 1. Praha.

LADOVÁ, M., 1960: Kutnohorské rejstř́iky počtů dolových 1472-1532, Př́íspěvky k dějinám Kutné Hory 1, $121-146$. 
LITOCHLEB, J., 1996: Pelhřimovský rudní revír. In: Stř́ibrná Jihlava 1996. Seminář k dějinám hornictví a důlních prací na Vysočině, 8-18. Jihlava.

LISSEK, P. a kol., 2014: Lissek, P.-Derner, K.-Šrein, V.-Bohdálek, P.-Křivánek, R., Výzkum hornického sídliště Kremsiger v roce 2013 - Untersuchung der Bergbausiedlung Kremsiger im Jahre 2013. In: ArchaeoMontan 2014. Ergebnisse und Perspektiven. Výsledky a výhledy - Arbeits- und Forschberichte der sächsischen Bodendenkmalpflege. Beiheft 29 (Smolnik, R., Hrsg.), 151-166. Dresden.

MAJER, J., 1967: K problematice báňské techniky 16. století v Jáchymově. In: Dolování v Jáchymově 15161966. Rozpravy Národního technického muzea 26, 128-140. Praha.

- 1968: Těžba stříbrných rud v Jáchymově v 16. století. In: Sborník Národního technického muzea 5, 111278. Praha.

- 1981: K vývoji české báňské praxe v 18. století, ZbSNM X, 53-78.

MALINA, O. a kol., v tisku: Malina, O.-Schneiderwinklová, P.-Augustýnová, M.-Černý, D., Středověká a novověká kolonizace v západním Krušnohoří. Hornictví jako příčina i následek. In: ArchaeoMontan 2018. Das Erzgebirge im Fokus der Montanarchäologie - Krušné hory v zájmu montánní archeologie. Arbeits- und Forschberichte der sächsischen Bodendenkmalpflege. Beiheft 32 (Smolnik, R.-Goryczková, N., edd.). Dresden - Loket.

MALÝ, K., 1998: Současný stav lokalit starého dolování v okolí Stříbrných Hor u Havlíčkova Brodu, Vlastivědný sborník Vysočiny - oddíl věd společenských 11, 45-58.

- 1999: Jihlavský rudní revír - přehled geologie a mineralogie. In: Dolování stříbra a mincování v Jihlavě, 15-27. Jihlava.

- 2001: Současný stav lokalit starého dolování v okolí České Bělé (okr. Havlíčkův Brod). In: Stříbrná Jihlava 2001. Seminář k dějinám hornictví a důlních prací na Vysočině, 61-65. Jihlava.

MAŠLOVÁ, K.-HRUBÝ, P., 2017: Nové poznatky k historické exploataci zlata na Vodňansku, Acta rerum naturalium 21, 151-162.

MINVIELLE LAROUSSE, N., 2017: L'âge del'argent. Mines, societé et pouvoir en Langudoc medieval. Thèse présentée pour obtenir le grade universitaire de Docteur. Discipline: Archéologie. Université d'Aix-Marseille. École doctorale 355 Espaces, Culturés, Sociétés.

PARMA, J. B., 1962: Vznik dobývacích metod v rudném hornictví a jejich vývoj do konce 19. století, Sborník pro dějiny prírodních věd a techniky VII, 137-158.

- 1970: K historickému vývoji otvírky a přípravných prací v rudném hornictví. In: Z dějin hornictví a hutnictví. Rozpravy Národního technického muzea, 59-68. Praha.

PETERS, J.-KOSCHIN, K., 1930: Horní zákony Československé platné v Čechách, na Moravě a ve Slezsku. Československý Kompas. Praha.

PLUSKAL, O.-VOSÁHLO, J., 1998: Jihlavský rudní obvod, Vlastivědný sborník Vysočiny 13, 157-191.

POŠVÁŘ, J., 1978: Společenské vztahy v Ius Regale Montanorum. In: Studie z dějin hornictví 9. Rozpravy Národního technického muzea, 15-28. Praha.

ROUS, P., 1998: Středověké hornické sídliště neznámého jména u Havlíčkova Brodu na k. ú. Termesivy. In: Stř́ibrná Jihlava 1998. Seminář k dějinám hornictví a důlních prací na Vysočině (Macek, L.-Malý, K., edd.), 102-115. Jihlava.

- 2001: K závěrečné fázi vrcholně středověkého hornictví na Havlíčkobrodsku. In: Stř́ibrná Jihlava 2001. Seminář k dějinám hornictví a důlních prací na Vysočině, 66-81. Jihlava.

- 2004: Stř́ibrorudné hornictví na Havlíčkobrodsku od 13. do 17. století, Archaeologia technica 15, 49-58.

- 2007: Povrchové stopy zpracování stř́ibrné rudy v poloze V Groubu na katastru obce Utín. In: Stř́íbrná Jihlava 2007. Studie k dějinám hornictví a důlních prací, 216-221. Jihlava.

ROZLOŽNÍK, L. a kol., 1987: Rozložník, L.-Havelka, J.-Čech, F.-Zorkovský, V., Ložiská nerastných surovín a ich vyhladávanie. Bratislava.

RICHTER, M., 1981: Zaniklá hornická osada u Klínce, Praehistorica VIII - Varia, Archaeologica 2, 301-306.

ROJÍK, P., 2000: Historie cínového hornictví v západním Krušnohoří. Sokolov.

SATTRAN, V.-ILAVSKÝ, J., edd., 1981: Metalogenetická mapa ČSSR (1 : 500 000). Ústřední ústav geologický - Kartografie Praha.

SMIRNOV, V. I., 1983: Geologie ložisek nerostných surovin. Praha.

SCHNEIDERWINKLOVÁ, P. a kol. 2018 v tisku: Schneiderwinklová, P.-Augustýnová, M.-Malina, O.Černý, D., Úprava a zpracování cínových rud v povodí Černé a Bystřice. In: ArchaeoMontan 2018. Das Erzgebirge im Fokus der Montanarchäologie - Krušné hory v zájmu montánní archeologie. Arbeits- und Forschberichte der sächsischen Bodendenkmalpflege. Beiheft 32 (Smolnik, R.-Goryczková, N., edd.). Dresden - Loket. 
SCHWABENICKY, W., 2007: Beziehungen zwischen mittelalterlichen Burgen und Bergbau. In: Stříbrná Jihlava 2007. Studie k dějinám hornictví a důlních prací, 130-147. Jihlava.

- 2009: Der mittelalterliche Silberbergbau im Erzgebirgsvorland und im westlichen Erzgebirge. Chemnitz.

STARÝ, J.-ŠANDEROVÁ, J.-TOMÁŠEK, M., 2007: Zaniklý těžební a zpracovatelský areál Hory u Vrbice. In: Stř́ibrná Jihlava 2007. Studie k dějinám hornictví a důlních prací, 102-113. Jihlava.

TOMÍČEK, R., 2007: Báňské zákonodárství v historii Královských horních měst Horní Slavkov, Krásno, Čistá. Horní Slavkov.

TRNKA, P., 2016: Diplomatika a správa kláštera Teplá ve druhé polovině 15. století. Disertační práce, ulož. na Katedře pomocných věd historických a archivního studia FF UK, Praha.

VANĚČEK, M., ed., 1995: Nerostné suroviny světa, rudy a nerudy. Praha.

VEČEŘA, J., 2008: Analýza povrchových tvarů Andělskohorského rudního revíru, část Hláska - Vysoká. In: Stř́ibrná Jihlava 2007. Studie k dějinám hornictví a důlních prací, 64-75. Jihlava.

- 2013: Průzkumná pole - klíč k rozluštění stř̌edověkých a novověkých děl? In: ArchaeoMontan 2012. Erkunden - Erfassen - Erforschen (Smolnik, R., Hrsg.), 45-58. Dresden.

-2015: Kolonizační snahy ve 13. století a nerostné bohatství Jeseníků, Forum urbes medii aevi VIII, č. 1-2, 25-30.

VEČĚ̌A, J.-VEČEŘOVÁ, V., 2006: Středověká hornická osada ve Zlatohorském rudním revíru - „Erlitz“ nebo Altenberg?, Archeologia technica 18, 60-63.

- 2013: Mapování a terénní rekognoskace pozůstatků po hornické činnosti v Krupce a Jáchymově (etapová zpráva za rok 2013). Rukopis. Národní památkový ústav, Územní odborné pracoviště v Ostravě.

VELÍMSKÝ, F., 2007: Nově evidované středověké montánní aktivity na Kutnohorsku. In:

Stříbrná Jihlava 2007. Studie k dějinám hornictví a důlních prací, 90-101. Jihlava.

- 2012: Zaniklý těžební areál U Všech Svatých na Horách Kutných, Acta Rerum Naturalium - Přírodovědný časopis Vysočiny 12, 203-209.

VELÍMSKÝ, F.-KONČELOVÁ, M., 2012: Archeologický výzkum zaniklého těžebního areálu u kostela sv. Václava v Pněvicích (okr. Kutná Hora), Acta Rerum Naturalium - Př́rodovědný časopis Vysočiny 12, 253-256.

VOSÁHLO, J., 2009: Hornictví mezi počátkem 16. století a dvacátými léty 17. století. In: Pisková, R. a kol., Jihlava, 286-303. Praha.

\section{Zusammenfassung}

\section{Bergbaureviere des Hochmittelalters und der frühen Neuzeit in vergleichender Perspektive}

Der Erkenntnisstand über historische Montanregionen hat in einer Reihe von Fällen ein solches Maß erreicht, das uns dazu zwingt, über ihre unterschiedlichen Entwicklungen nachzudenken. Ein Vergleich ganzer Reviere kann einen Interpretationskontext mit neuen Möglichkeiten anbieten, selbst wenn dieser immer noch von einer unzureichenden Quellengrundlage begrenzt wird. Geeignete Fragen bietet sich eine ganze Reihe an, sei es über die absolute als auch relative Chronologie der wichtigsten Abbauphasen, die unterschiedlich funktionierende Organisation der Verarbeitungs- und Hüttenbetriebe oder die lokal jeweils spezielle Beziehung zwischen Bergbau und Besiedelung. Hauptbestreben des vorliegenden Textes ist es, einen besseren Kenntnisstand über die Reviere und ihre Schlüsselfundstellen dort zu ermöglichen, wo uns wichtige Quellen zu ihrer Entwicklung fehlen. Dazu sollen vor allem geeignete Analogien dienen, die anhand von gut definierten Kriterien ausgewählt wurden.

Im ersten Teil des Textes widmen wir uns der Definition des Begriffes Revier als einer größeren räumlichen Grundeinheit unseres Interesses. Der zweite Teil formuliert die Grundtypen zentraler Standorte als natürliche Brennpunkte der Reviere, die Einzugsgebiete gehabt haben müssen. Der letzte Teil konzentriert sich auf das Bestreben, universale Entwicklungsphasen der Reviere zu definieren, die in den Vergleichsregionen verzeichnet werden konnten. Die Grundlage des Textes bilden die Erkenntnisse aus den vier Vergleichsregionen, von denen wir einen besseren Erkenntnisstand haben - die Böhmisch-Mährische Höhe, das östliche und westliche Erzgebierge und Zlaté Hory in Schlesien. 
Schon allein die Definition der Vergleichskriterien der Reviere ermöglicht einen besseren Überblick über die Möglichkeiten der Montanarchäologie, der Geologie und der Geschichte des Bergbaus sowie der daran anknüpfenden Naturwissenschaften im breiteren Kontext und zeigt auf, in welchen Revieren es Sinn macht, für konkrete Fragen die besten Antworten zu suchen. Der erste erforderliche Schritt einer solchen Arbeit ist jedoch die Auswahl der grundlegenden Methoden. In unserem Text haben wir uns auf eine geologische, eine montanhistorische und auf eine archäologische Herangehensweise an den Begriff Revier konzentriert. Jede von ihnen liefert ein unterschiedliches Bild, und obwohl es zweckdienlich ist, sie zu kombinieren, müssen auch die Grenzen der genannten Wissenschaften erwähnt werden.

Die geologische Sichtweise hing deutlich vom Grad des Erkenntnisstandes über die Gesetzmäßigkeit der Lagerstätten und von ihrer historischen Entwicklung ab. Das Problem von Revieren nach schriftlichen Quellen ist in der Regel eine fehlende räumliche Abgrenzung. Die montanhistorische Sichtweise ist bestrebt, beide Herangehensweisen von Anfang an miteinander zu kombinieren. Grundlage unserer archäologischen Herangehensweise ist vor allem das montane Geländerelief und Orte mit einem größeren archäologischen Potenzial, am häufigsten mit einer Bergbautätigkeit zusammenhängende Siedlungsrelikte. Sehr wichtig sind auch die Daten eines luftgestützten Laserscannings und das von ihnen abgeleitete Digitalmodell des Geländereliefs. Dieses liefert sowohl eine gute Detailliertheit, als auch eine große räumliche Dimension, die den Revieren, was die geologischen als auch montan-administrativen Kriterien anbelangt, entspricht.

Bestandteile unserer Bemühung um eine Definition der Vergleichseinheiten sind außer dem jeweils verschieden definierten Revier auch das Bergbauareal, der Distrikt und der Bezirk als Teil der Montanlandschaft, die vor allem anhand des Geländereliefs abgrenzbar ist, und das am besten anhand von schriftlichen (montan-administrativen) Quellen definierbare Bergbaugebiet.

Eine wichtige Rolle bei der Formung von Revieren spielten unserer Meinung nach ihre zentralen Standorte. Deshalb spiegelt der zweite Teil des Textes das Bestreben wider, eine gewisse Klassifizierung in Grundtypen vorzunehmen, die vorerst in allen vier behandelten Gebieten definiert werden konnten.

Der erste Standorttyp sind große mittelalterliche Bergbausiedlungen und mittelalterliche und neuzeitliche Bergbaustädte, die in ihrem differenzierten Vorkommen und mit einer jeweils unterschiedlichen Chronologie interessant sind. Der zweite Typ sind auf der Böhmisch-Mährischen Höhe definierte Groß- und Kleinbetriebe, die wir mit passenden Analogien aus anderen Revieren in Verbindung zu bringen bestrebt sind. Montanen Standorten mit umfriedeten Arealen und ihrer schwierigen Interpretation wird ebenfalls Aufmerksamkeit geschenkt.

Der letzte Teil des Textes enthält ein Definition universaler Trends, die in verschiedenen Revieren wiederholt auftraten und uns dabei behilflich sein können, ihre Entwicklung richtig zu interpretieren. Um Kenntnisse über die ältesten Etappen der Montanregionen zu erlangen, sind frühe schriftliche Erwähnungen von Revieren von Schlüssebedeutung. Die Erkundungsetappe und die frühe Exploitation wurden in beträchtlichem Maße vom Siedlungs- und Agrarhinterland beeinflusst, sodass hier auch die unterschiedliche geographische Disposition der beobachteten Regionen eine Rolle gespielt hat. Die meisten Erkenntnisse über Bergbauareale beziehen sich für gewöhnlich in größerem Maße auf die Hauptabbauphase primärer Lagerstätten, die archäologisch am besten lesbar zu sein pflegen. Ein Problem stellen jedoch Wiederaufnahmeetappen dar, die in vielen Revieren sehr häufig vorkamen. Um so wertvoller sind solche Reviere oder Teile von ihnen, die nur während einer historischen Etappe genutzt wurden und uns so am besten Erkenntnisse über sie liefern können. Unter den wiederholt auftretenden Faktoren werden auch die Höhenfolge (Teufenfolge) der Stollen und Grubenfelder (Grubenmaßen) erwähnt, deren Größe häufig historisch bedingt war und uns auch dort eine chronologische Grundorientierung erlaubt, wo uns schriftliche Quellen fehlen. 
Die vorliegende Studie entstand bei der Umsetzung des Projektes Nachhaltige Entwicklung der Kulturlandschaft und Schutz historischer Denkmäler in Waldgebieten, Projektcode: TL02000111.

MUDr. et Mgr. Kryštof Derner, Jana Žižky 835, 43401 Most, Česká republika, KDerner@seznam.cz

doc. Mgr. Petr Hrubý, Ph.D., Ústav archeologie a muzeologie Filozofické fakulty Masarykovy univerzity, Arna Nováka 1, 60200 Brno, Česká republika, PetrSilberbergbau@seznam.cz

Mgr. Ondřej Malina, Ph.D., Kostelní 81/25, 35733 Loket, Česká republika, malina.ondrej@npu.cz; omalin@seznam.cz

RNDr. Josef Večeřa, Erbenova 348, 79001 Jeseník, Česká republika,josef.vecera@geology.cz smluvní licence nebo výjimky či omezení př́islušných práv. 
